\title{
Leaf beetles are ant-nest beetles: the curious life of the juvenile stages of case-bearers (Coleoptera, Chrysomelidae, Cryptocephalinae)
}

\author{
Federico A. Agrain', Matthew L. Buffington², Caroline S. Chaboo ${ }^{3}$, \\ Maria L. Chamorro ${ }^{4}$, Matthias Schöller ${ }^{5}$
}

I Laboratorio de Entomología, IADIZA, CCT-CONICET, CC507, 5500, Av. A. Ruiz Leal s/n, Pque. Gral. San Martin, Mendoza, Argentina 2 Systematic Entomology Laboratory, ARS-USDA, MRC 168, National Museum of Natural History, Smithsonian Institution P.O. Box 37012, Washington, DC, 20013-7012, U.S.A. 3 Division of Entomology, 1501 Crestline Drive, Suite 140, University of Kansas, Lawrence, KS, 66045, U.S.A. 4 Systematic Entomology Laboratory, ARS-USDA, MRC 168, National Museum of Natural History, Smithsonian Institution P.O. Box 37012, Washington, DC, 20013-7012, U.S.A. 5 Humboldt-Universität zu Berlin, Faculty of Life Sciences, Lentzeallee 55/57, 14195 Berlin, Germany

Corresponding author: Federico A. Agrain (fagrain@mendoza-conicet.gov.ar)

Academic editor: M. Schmitt | Received 26 June 2015 | Accepted 12 November 2015 | Published 17 December 2015

http://zoobank.org/2D10C2DB-OF8A-403C-A28E-50E63CC33F42

Citation: Agrain FA, Buffington ML, Chaboo CS, Chamorro ML, Schöller M (2015) Leaf beetles are ant-nest beetles: the curious life of the juvenile stages of case-bearers (Coleoptera, Chrysomelidae, Cryptocephalinae). In: Jolivet P, SantiagoBlay J, Schmitt M (Eds) Research on Chrysomelidae 5. ZooKeys 547: 133-164. doi: 10.3897/zookeys.547.6098

\begin{abstract}
Although some species of Cryptocephalinae (Coleoptera: Chrysomelidae) have been documented with ants (Hymenoptera: Formicidae) for almost 200 years, information on this association is fragmentary. This contribution synthesizes extant literature and analysizes the data for biological patterns. Myrmecophily is more common in the tribe Clytrini than in Cryptocephalini, but not documented for Fulcidacini or the closely-related Lamprosomatinae. Myrmecophilous cryptocephalines (34 species in 14 genera) primarily live among formicine and myrmecines ants as hosts. These two ant lineages are putative sister-groups, with their root-node dated to between 77-90 mya. In the New World tropics, the relatively recent radiation of ants from moist forests to more xeric ecosystems might have propelled the association of cryptocephalines and ant nests. Literature records suggest that the defensive behavioral profile or chemical profile (or both) of these ants has been exploited by cryptocephalines. Another pattern appears to be that specialized natural enemies, especially parasitoid Hymenoptera, exploit cryptocephaline beetles inside the ant nests. With the extant data at hand, based on the minimum age of a fossil larva dated to 45 mya, we can infer that the
\end{abstract}

Copyright Federico A. Agrain et al. This is an open access article distributed under the terms of the Creative Commons Attribution License (CC BY 4.0), which permits unrestricted use, distribution, and reproduction in any medium, provided the original author and source are credited. 
origin of cryptocephaline myrmecophily could have arisen within the Upper Cretaceous or later. It remains unknown how many times myrmecophily has appeared, or how old is the behavior. This uncertainty is compounded by incongruent hypotheses about the origins of Chrysomelidae and angiosperm-associated lineages of cryptocephalines. Living with ants offers multiple advantages that might have aided the colonization of xeric environments by some cryptocephaline species.

\section{Keywords}

Myrmecophily, Camptosomata, Larvae, Biology, Clytrini, Cryptocephalini

\section{Introduction}

With approximately 40,000 species documented, the Chrysomelidae, commonly called leaf beetles, are one of the most diverse insect groups on Earth. They are well known as phytophages, specializing on all parts of plants, from roots to fruits and flowers. Within this broad lineage, whose origin has been dated from the Middle Jurassic (Wang et al. 2014), numerous instances of plant host-switching have been recorded with clades specialized on certain plant families. In some immature stages, we also find remarkable diet switching to detritivory and myrmecophily ("ant loving"). Such habitat and diet shifts involve behavioral, morphological and chemical changes, yet these are unevenly or poorly studied across Chrysomelidae.

This study focuses on the monophyletic Camptosomata branch of leaf beetles (Gómez-Zurita et al. 2008, and references therein), comprised of two subfamilies: Cryptocephalinae Gyllenhal (127 genera; $c$. 5300 species) and Lamprosomatinae Lacordaire (13 genera; $c a .250$ species) (Chamorro 2014a, b). Cryptocephalinae is currently classified into 3 subtribes: Fulcidacini, Clytrini, and Cryptocephalini. Camptosomata has been poorly studied despite its large diversity within Chrysomelidae and several remarkable features in their life cycle, behavior and morphology.

Camptosomates are commonly referred to as "case-bearers" because of the unusual larval behavior of retaining a maternal covering of feces around each egg, carrying and reconstructing it as a protective structure, and ultimately modifying it as a pupation chamber. Schaller (1783) is the first illustrated description of a leaf beetle larvae carrying a case. Since then, Erber's (1988) synthesis of camptosomate case-bearing behavior has helped us recognize this behavior as a synapomorphy of Cryptocephalinae + Lamprosomatinae. The case functions as a domicile and protective covering from environmental conditions (e.g. desiccation) and/or from predators and parasitoids (e.g., camouflage). The Greek name "camptosomata", literally "curved body", was established by Chapuis (1874) (Camptosomes), presumably describing the characteristic J-shape of the soft larva in both Cryptocephalinae and Lamprosomatinae. This curvature results in the anus being located near the legs, so fecal pellets are more easily manipulated in case construction (Erber 1988). Brown and Funk (2005) studied the morphological variation across life stages, construction 
behavior, and investigated some functions in one species. Two recent treatments on Camptosomata, Chamorro (2014a, b) for adults and a catalog by Chaboo et al. (in press) for juveniles, can now stimulate recognition of new ecological and evolutionary patterns in Camptosomata and aid future research on this major branch of leaf beetles. Chaboo et al. (in press) searched literature records for 354 species (6.7\%) of the 5300 recognized camptosomate species, and documented multiple instances of host ant associations (in contrast to the commonly known host plant use of both adult and larvae).

Although myrmecophilous associations can be found in at least 35 beetle families, including varied behavioral and morphological characteristics (Mynhardt 2013), it is not widely known among entomologists, even among ant and leaf beetle biologists, that some Camptosomata appear to seek food and shelter in ant nests. This paper builds on Chamorro (2014a, b) and Chaboo et al. (in press) to further synthesize the literature record, bring focus to the association of some Cryptocephalinae species with ants, and evaluate what pattern, if any, exists.

Chevrolat (1835) was the first to mention case-bearing leaf beetles inside ant nests. Although myrmecophily in leaf beetles has been known for almost 200 years, it remains poorly studied. Within the Chrysomelidae, myrmecophily has evolved in two subfamilies, Eumolpinae, and Cryptocephalinae (Jolivet and Petitpierre 1981, and references therein). Of the 354 species for which some data on juvenile stages exist, only Clytrini and some Cryptocephalini exhibit myrmecophily (Jolivet 1988, Fig. 1 A-D). To date, no case of myrmecophily has been documented for Fulcidacini (the third tribe of Cryptocephalinae) and Lamprosomatinae.

Jolivet (1952) published on myrmecophily for Lachnaia Chevrolat and Tituboea Lacordaire. Brothers et al. (2000) reported that approximately 20 species of Clytrini are commensals in the nests of more than 30 ant species; yet, a small number of these associations are formally documented. Schöller and Witte (2007) hypothesized myrmecophily as a synapomorphy at least for the subtribe Clytrina, however, a phylogeny of this subtribe and the Camptosomata clade and more detailed observations and broader taxon sampling are needed to understand the full picture of these leaf beetle association with ants.

Ants are not the only hosts of some Camptosomata. Griburius montezuma (Cryptocephalini) has been reported as living in nets of bird (Beamer 1926) and of packrats Neotoma Say \& Ord, 1825 (Mammalia: Rodentia; Riley et al. 2001, Riley et al. 2002). Oomorphus Curtis (Lamprosomatinae) larvae were also found in packrat nests (Flowers et al. 1994, Riley et al. 2002, Jolivet and Verma 2002). Nothing is known about these peculiar associations; it might be that these larvae were accidentally introduced in these nests (i.e. incorporated through plant materials). However, we cannot ignore that in nature there are several examples of commensals, saprophages, hibernators, occupying these kind of habitats, thus their presence in these nests might indicate a remarkable new association that requires further study. We will not discuss this association further in this paper. 


\section{Challenges of myrmecophily}

Ant nests are considered to be well-protected environments, with storage of food items and stable microclimatic conditions. Wilson (1971) and Hölldobler (1972) argued that the insect colony and its immediate environment can be compared to an ecological island, partitioned into many micro-habitats that symbiotic organisms are continuously attempting to colonize. Several myrmecophilous organisms are known to profit from these assets by inhabiting them (Geiselhardt et al. 2007, and references therein). In fact, more than 10,000 social parasite species have been reported in ant nests (Thomas et al. 2005). Coleopterans are common commensals in ant nests (Hölldobler and Wilson 1990). For cryptocephalines, this relationship is based only on the documented presence of the beetle in the ant nest. The degree and quality of the relationship has not been investigated except for a few species for which life histories are known.

The exploitation of ant nests presents some formidable challenges. Wilson (1971) remains the classic overview to non-ants living with ants. Finding the host ants, especially the nest, is the first challenge, but entering the fortress of these aggressive and hostile animals requires behavioral, morphological, and chemical changes to fool the host. A myrmecophile can live outside the nest, being associated with ant trails and even migrating with the ants as they move; they could follow trails or hitchhike on the ants. The host ant can be tricked into carrying invaders inside the nest, and even into feeding them. For example, adult clavigerine staphylinid beetles have glands with oily secretions and associated trichomes that wick the chemicals and fool their host ants into carrying them into the nest and feeding them (Kistner 1982). There may also be great morphological changes to mimic ants, as seen in other beetle groups (e.g. Myrmex Sturm (Curculionidae: Otidocephalini). Once accepted inside the ant nest, the 'uninvited guest' insect has some trophic options as predators (of ants or other arthropod inhabitants), scavengers (nest refuse, dead bodies), fungivores, herbivores (eating stored grain and leaves), parasitoids, and thieves (e.g. regurgitated food). An invading insect can also choose from a variety of places or niches to live, such as refuse piles, storage chambers, and brood chambers. Research is more advanced on other insect mymecophiles (e.g. Carabidae: Paussinae; Staphylinidae) and may provide useful models to guide research on the cryptocephaline myrmecophiles.

\section{Materials and methods}

Existing literature on ant-camptosome associations was synthesized (Table 1). Beetle names were validated in Chaboo et al. (in press), with family- and genus-group names and authors following Bouchard et al. (2011), Löbl and Smetana (2010), and Seeno and Wilcox (1982). Ant names were validated using AntWeb (http://www.antweb. org). In order to trace the evolution of cryptocephaline myrmecophiles and their hosts, existing information on the phylogenetic patterns among Formicidae was extracted from Moreau and Bell (2013), Brady et al. (2006), Rabelling et al. (2008), and Schultz 
and Brady (2008). Author's names for all genera and species of ants and beetles cited in the text are given in Table 1.

Terminology: we use the terms 'myrmecophily' and 'myrmecophilous' in a broad sense, meaning casual or intimate association of the beetle with ants. Such interactions could involve different forms, from mutualism (benefits for both associates), parasitism (host resources necessarily drained for parasite's own reproduction), commensalism (with no direct effect on the host), predation (direct feeding/damage to the host), or inquilinism (the 'guest' obtains shelter and other resources from the host without damaging host). For extended definitions and discussion of the latter terms see Parmentier and Michel (2013 and references therein). Myrmecophiles are often differentiated as 'protective' or 'symphiles' according to their strategies (Geiselhard et al. 2007 and references therein). We also follow Mynhardt (2013 and references therein), as a glossary and modern critique of the terms historically used in the study of myrmecophily.

Figure 1 photographs were taken by Matthias Schöller with a Nikon D5100 mounted on a stereo microscope, and the photos stacked with CombineZP software (http://www.hadleyweb.pwp.blueyonder.co.uk).

\section{Results}

Our synthesis of the literature reveals that 34 species of Cryptocephalinae have been associated with ants. The following ant groups host cryptocephalines: Dolichoderinae (1 species), Dorylinae (1 species) Formicinae (13 species), Myrmicinae (16 species); 11 species were reported on an undetermined host ant. Of the latter, 4 cryptocephaline genera are included in this category for which there is no other ant record. These associations represent approximately $0.6 \%$ of current species diversity of Cryptocephalinae. In summary, $14 \%$ of the 127 Cryptocephalinae genera are associated with ants at some level, as truly myrmecophilous. We found several previously unnoticed patterns in the ant associations of camptosomate genera and species. Regarding the extent of myrmecophily within Camptosomata, we found that ant associations are documented only in two tribes, Clytrini and Cryptocephalini (Fig. 1). Both tribes show distinct patterns of ant association - clytrines appear to be able to exploit several subfamilies of ants, including Formicinae, Myrmicinae, Dolichoderinae, and Dorylinae, while cryptocephalines appear to be restricted to the Formicinae and Myrmicinae.

Data extracted from literature and synthesized here suggest that myrmecophily in Cryptocephalinae is rare or simply unknown, being more frequent in Clytrini (Fig. 2 A-F). Cryptocephalini is currently composed of 54 genera (Chamorro 2014b). Out of these, six genera of Cryptocephalini (11\%), have records of association with ants, while Clytrini has 62 genera (Chamorro 2014b), with 12 genera (19\%) associated with ants (Table 2). Within the Clytrini, almost all documented cases of myrmecophily are in the subtribe Clytrina, except for two genera in the subtribe Megalostomina (i.e. Coscinoptera, and Megalostomis) and two genera in Babiina (Helioscopa, Saxinis). 
Table I. Known ant host of Cryptocephalinae. CL=Clytrini, CR=Cryptocephalini.

\begin{tabular}{|c|c|c|c|}
\hline Taxon & Beetle species & Tribe & Source \\
\hline \multicolumn{4}{|c|}{ Dolichoderinae ants } \\
\hline $\begin{array}{l}\text { Tapinoma erraticum } \\
\text { Latreille }\end{array}$ & Labidostomis taxicornis (Fabricius) & CL & Barbier 1976, Erber 1988 \\
\hline \multicolumn{4}{|c|}{ Dorylinae ants } \\
\hline Dorylus sp. & $\begin{array}{c}\text { Clytrinae larvae follow the migrations } \\
\text { of their hosts outside the nest during } \\
\text { day or night }\end{array}$ & $\mathrm{CL}$ & Jolivet 1952 \\
\hline \multicolumn{4}{|c|}{ Formicinae ants } \\
\hline Camponotus sp. & Clytra (Clytra) laeviuscula Ratzeburg & $\mathrm{CL}$ & Paulian and Villiers 1939 \\
\hline $\begin{array}{l}\text { Camponotus ligniperdus } \\
\text { Latreille }\end{array}$ & Clytra (Clytra) quadripunctata (L.) & CL & $\begin{array}{c}\text { Wasmann 1894a, Skwarra } \\
\text { 1927, Jolivet 1952, } \\
\text { Medvedev } 1962 \\
\end{array}$ \\
\hline Camponotus (Latreille) & Clytra sp. & $\mathrm{CL}$ & $\begin{array}{c}\text { Medvedev 1962, Lee and } \\
\text { Morimoto 1991, Jolivet and } \\
\text { Hawkeswood } 1995\end{array}$ \\
\hline Camponotus melleus Say & $\begin{array}{l}\text { Coscinoptera dominicana dominicana } \\
\text { (Fabricius) }\end{array}$ & $\mathrm{CL}$ & $\begin{array}{l}\text { Wasmann 1894a, Cockerell } \\
\text { (1891) }\end{array}$ \\
\hline $\begin{array}{l}\text { Camponotus (Myrmosericus) } \\
\text { rufoglaucus Jerdon }\end{array}$ & Hockingia curiosa Selman & CL & Selman 1962 \\
\hline Camponotus sp. & Clytrasoma maschwitzi Schöller & $\mathrm{CL}$ & Schöller and Witte 2007 \\
\hline Camponotus sp. & Clytra (Clytra) quadripunctata (L.) & & \\
\hline Camponotus & Clytrine & $\mathrm{CL}$ & Jolivet 1978 \\
\hline $\begin{array}{l}\text { Cataglyphis cursor } \\
\text { Fonscolombe }\end{array}$ & Clytra (Clytraria) atraphaxidis (Pallas) & $\mathrm{CL}$ & Xambeu 1899, Jolivet 1952 \\
\hline $\begin{array}{l}\text { Cataglyphis bicolor } \\
\text { (Fabricius) }\end{array}$ & Clytra (Clytraria) atraphaxidis (Pallas) & CL & Medvedev 1962 \\
\hline $\begin{array}{l}\text { Cataglyphis cursor } \\
\text { Fonscolombe }\end{array}$ & Clytra (Clytraria) atraphaxidis (Pallas) & CL & Jolivet (1952) \\
\hline Cataglyphis bicolor Fabricius & Clytra (Clytraria) atraphaxidis (Pallas) & $\mathrm{CL}$ & $\begin{array}{c}\text { Xambeu (1899), Medvedev } \\
\text { (1962) }\end{array}$ \\
\hline Cataglyphis Förster & Clytra sp. & $\mathrm{CL}$ & $\begin{array}{c}\text { Medvedev 1962, Lee and } \\
\text { Morimoto 1991, Jolivet and } \\
\text { Hawkeswood } 1995 \\
\end{array}$ \\
\hline $\begin{array}{l}\text { Cataglyphis cursor } \\
\text { Fonscolombe }\end{array}$ & $\begin{array}{l}\text { Lachnaia (Lachnaia) tristigma } \\
\text { (Lacordaire) }\end{array}$ & CL & Medvedev 1962 \\
\hline $\begin{array}{l}\text { Cataglyphis cursor } \\
\text { Fonscolombe }\end{array}$ & $\begin{array}{l}\text { Lachnaia (Lachnaia) tristigma } \\
\text { (Lacordaire) }\end{array}$ & $\mathrm{CL}$ & Xambeu 1899 \\
\hline Cataglyphis Förster & Lachnaia Chevrolat in Dejean & $\mathrm{CL}$ & $\begin{array}{c}\text { Jolivet and Hawkeswood } \\
1995\end{array}$ \\
\hline $\begin{array}{l}\text { Formica pallidefulva } \\
\text { Latreille }\end{array}$ & Anomoea flavokansiensis Moldenke & $\mathrm{CL}$ & $\begin{array}{c}\text { Stiefel et al. 1995, LeSage } \\
\text { and Stiefel 1996, Stiefel and } \\
\text { Margolies } 1998 \\
\end{array}$ \\
\hline Formica sanguinea Latreille & Clytra (Clytra) laeviuscula Ratzeburg & CL & $\begin{array}{c}\text { Wasmann 1894a, } \\
\text { Donisthorpe 1927, Jolivet } \\
\text { 1952, Lapeva-Gjonova } 2013\end{array}$ \\
\hline Formica pratensis DeGeer & Clytra (Clytra) laeviuscula Ratzeburg & $\mathrm{CL}$ & $\begin{array}{c}\text { Wasmann 1894a, Skwarra } \\
\text { 1927, Jolivet } 1952\end{array}$ \\
\hline Formica fusca L. & Clytra (Clytra) laeviuscula Ratzeburg & CL & Reineck 1928, Erber 1988 \\
\hline
\end{tabular}


Table I.Continued.

\begin{tabular}{|c|c|c|c|}
\hline Taxon & Beetle species & Tribe & Source \\
\hline Formica rufa L. & Clytra (Clytra) quadripunctata (L.) & CL & $\begin{array}{l}\text { Chevrolat 1835, Märkel } \\
\text { 1841, Rosenhauer 1842, } \\
\text { Brauns 1864, Collet 1883, } \\
\text { Fowler 1890, Wasmann } \\
\text { 1894a, Donisthorpe } \\
\text { 1908, Donisthorpe 1927, } \\
\text { Skwarra 1927, Jolivet 1952, } \\
\text { Medvedev 1962, Lapeva- } \\
\text { Gjonova 2013 }\end{array}$ \\
\hline Formica rotundata Klug & Clytra (Clytra) quadripunctata (L.) & $\mathrm{CL}$ & Medvedev 1962, Erber 1988 \\
\hline Formica exsecta Nylander & Clytra (Clytra) quadripunctata (L.) & $\mathrm{CL}$ & $\begin{array}{c}\text { Brauns 1864, Wasmann } \\
\text { 1894b, Skwarra 1927, Jolivet } \\
\text { 1952, Medvedev } 1962\end{array}$ \\
\hline $\begin{array}{c}\text { Possibly Formica congerens } \\
\text { Nylander }\end{array}$ & Clytra (Clytra) quadripunctata (L.) & CL & Hislop 1872 \\
\hline Formica sanguinea Latreille & Clytra (Clytra) quadripunctata (L.) & CL & $\begin{array}{c}\text { Wasmann 1894a, } \\
\text { Skwarra 1927, Jolivet } \\
\text { 1952, Medvedev 1962, } \\
\text { Medvedev } 1962\end{array}$ \\
\hline Formica pratensis DeGeer & Clytra (Clytra) quadripunctata (L.) & CL & $\begin{array}{l}\text { Skwarra 1927, Jolivet 1952, } \\
\text { Wasmann 1894a, Erber } 1988 \\
\end{array}$ \\
\hline Formica rufo-pratensis Forel & Clytra (Clytra) quadripunctata (L.) & $\mathrm{CL}$ & Skwarra 1927, Erber 1988 \\
\hline $\begin{array}{c}\text { Formica pressilabris } \\
\text { Nylander }\end{array}$ & Clytra (Clytra) quadripunctata (L.) & $\mathrm{CL}$ & Skwarra 1927, Erber 1988 \\
\hline Formica gagates Nylander & Clytra (Clytra) quadripunctata (L.) & $\mathrm{CL}$ & $\begin{array}{c}\text { Wasmann 1894a, Skwarra } \\
\text { 1927, Jolivet 1952, } \\
\text { Medvedev } 1962\end{array}$ \\
\hline Formica uralensis Ruzsky & Clytra (Clytra) quadripunctata (L.) & $\mathrm{CL}$ & $\begin{array}{c}\text { Skwarra 1927, Medvedev } \\
1962\end{array}$ \\
\hline Formica sp. & Clytra (Clytra) quadripunctata (L.) & $\mathrm{CL}$ & Priefert 1926, Selman 1988 \\
\hline Formica rufa L. & Clytra sp. & CL & Chevrolat 1835 \\
\hline Formica L. & Clytra sp. & CL & $\begin{array}{c}\text { Medvedev 1962, Lee and } \\
\text { Morimoto 1991a }\end{array}$ \\
\hline Formica fusca $\mathrm{L}$. & Clytra sp. & $\mathrm{CL}$ & Medvedev 1962 \\
\hline Formica fusca $\mathrm{L}$. & Clytra sp. & $\mathrm{CL}$ & $\begin{array}{l}\text { Samšinák 1956, } \\
\text { Medvedev } 1962\end{array}$ \\
\hline Formica sp. & $\begin{array}{c}\text { Coscinoptera dominicana dominicana } \\
\text { (Fabricius) }\end{array}$ & CL & Riley $1874 \mathrm{~b}$ \\
\hline Formica obscuripes Forel & $\begin{array}{c}\text { Coscinoptera dominicana dominicana } \\
\text { (Fabricius) }\end{array}$ & $\mathrm{CL}$ & Riley $1874 \mathrm{~b}$ \\
\hline Formica selysii Bondroit & $\begin{array}{l}\text { Pachybrachis anoguttatus Suffrian } \\
\text { (found inside the ant nest) }\end{array}$ & $\mathrm{CR}$ & Schöller 1995 \\
\hline $\begin{array}{l}\text { Formica fusca subaenescens } \\
\text { Emerton }\end{array}$ & $\begin{array}{l}\text { Coscinoptera dominicana dominicana } \\
\text { (Fabricius) }\end{array}$ & CL & $\begin{array}{c}\text { Jolivet 1952, Wasmann } \\
1894 \mathrm{a}\end{array}$ \\
\hline Formica obscuripes Forel & $\begin{array}{l}\text { Coscinoptera dominicana dominicana } \\
\text { (Fabricius) }\end{array}$ & CL & $\begin{array}{c}\text { Cockerell 1891, Jolivet 1952, } \\
\text { Riley } 1874\end{array}$ \\
\hline Formica neoclara Emery & $\begin{array}{c}\text { Coscinoptera dominicana franciscana } \\
\text { (LeConte) }\end{array}$ & CL & Slosser 2003 \\
\hline
\end{tabular}


Table I.Continued.

\begin{tabular}{|c|c|c|c|}
\hline Taxon & Beetle species & Tribe & Source \\
\hline $\begin{array}{l}\text { Formica fusca subaenescens } \\
\text { Emerton }\end{array}$ & Coscinoptera vittigera (LeConte) & CL & $\begin{array}{l}\text { Wasmann 1894a, } \\
\text { Jolivet } 1952\end{array}$ \\
\hline Formica fusca L. & $\begin{array}{c}\text { Coscinoptera vittigera Probably } C . \\
\text { dominicana (Fabricius) }\end{array}$ & CL & $\begin{array}{l}\text { Cockerell 1891, Wasmann } \\
\text { 1894a, Jolivet } 1952\end{array}$ \\
\hline Formica & Clytrine & $\mathrm{CL}$ & Jolivet 1978 \\
\hline Lasius niger $\mathrm{L}$. & $\begin{array}{c}\text { Cryptocephalus (Burlinius) ocellatus } \\
\text { ocellatus Drapiez }\end{array}$ & CR & Schöller 1995 \\
\hline Lasius niger $\mathrm{L}$. & Clytra (Clytra) laeviuscula Ratzeburg & CL & $\begin{array}{c}\text { Fiori 1948, Wasmann 1894a, } \\
\text { Erber } 1988\end{array}$ \\
\hline Lasius alienonigra Forst. & Clytra (Clytra) laeviuscula Ratzeburg & $\mathrm{CL}$ & Skwarra 1927, Erber 1988 \\
\hline Lasius alienus Forst. & Clytra (Clytra) laeviuscula Ratzeburg & CL & $\begin{array}{c}\text { Skwarra 1927, Fiori 1948, } \\
\text { Erber } 1988\end{array}$ \\
\hline $\begin{array}{l}\text { Lasius neglectus Van Loon, } \\
\text { Boomsma \& András-Falvy }\end{array}$ & Clytra (Clytra) laeviuscula Ratzeburg & $\mathrm{CL}$ & $\begin{array}{c}\text { Selman } 1988 \text {, Espadaler and } \\
\text { Bernal } 2009\end{array}$ \\
\hline Lasius niger $\mathrm{L}$. & Clytra (Clytra) laeviuscula Ratzeburg & $\mathrm{CL}$ & Donisthorpe 1927 \\
\hline Lasius niger $\mathrm{L}$. & Clytra (Clytra) laeviuscula Ratzeburg & $\mathrm{CL}$ & Donisthorpe 1927 \\
\hline Lasius flavus (DeGeer) & Clytra (Clytra) quadripunctata (L.) & CL & $\begin{array}{c}\text { Wasmann 1894a, Skwarra } \\
\text { 1927, Jolivet 1952, } \\
\text { Medvedev } 1962 \\
\end{array}$ \\
\hline Lasius Latreille & Clytra sp. & CL & $\begin{array}{c}\text { Medvedev 1962, Lee and } \\
\text { Morimoto 1991, Jolivet and } \\
\text { Hawkeswood } 1995\end{array}$ \\
\hline $\begin{array}{l}\text { Lasius neglectus Van Loon, } \\
\text { Boomsma \& András-Falvy }\end{array}$ & Clytrinae larvae & $\mathrm{CL}$ & Nagy et al. 2009 \\
\hline Lasius fuliginosus Latreille & $\begin{array}{c}\text { Cryptocephalus (Burlinius) fulvus fulvus } \\
\text { (Goeze) }\end{array}$ & CR & Donisthorpe 1927 \\
\hline Plagiolepis sp. & Tituboea macropus (Illiger) & CL & Medvedev 1962, Erber 1988 \\
\hline \multicolumn{4}{|c|}{ Myrmicinae ants } \\
\hline $\begin{array}{l}\text { Aphaenogaster subterranea } \\
\text { Latreille }\end{array}$ & Clytra (Clytra) laeviuscula Ratzeburg & CL & Fiori 1948, Erber 1988 \\
\hline $\begin{array}{c}\text { Aphaenogaster }(\text { Myrmica }) \\
\text { testaceopilosa Lucas }\end{array}$ & Tituboea octosignata (Fabricius) & CL & Lucas 1850 \\
\hline $\begin{array}{c}\text { Aphaenogaster testaceopilosa } \\
\text { Lucas }\end{array}$ & Cryptocephaline & Undetermined & $\begin{array}{c}\text { Wasmann 1894a, Xambeu } \\
\text { 1899, Medvedev 1962, } \\
\text { Jolivet } 1952\end{array}$ \\
\hline $\begin{array}{l}\text { Atta mexicana (F. Smith) } \\
\text { (Larvae saprophagous) }\end{array}$ & Megalostomis dimidiata Lacordaire & CL & $\begin{array}{c}\text { Rojas 1989, Navarrete- } \\
\text { Heredia (2001) (as } \\
\text { accidental) }\end{array}$ \\
\hline Atta Fabricius & Megalostomis dimidiata Lacordaire & $\mathrm{CL}$ & Moldenke 1970 \\
\hline Atta nest (digging on) & Megalostomis dimidiata Lacordaire & $\mathrm{CL}$ & Agrain 2010 \\
\hline Atta texana (Buckley) & $\begin{array}{l}\text { Megalostomis dimidiata Lacordaire } \\
\text { (as M. major Crotch). } 2.5 \mathrm{~m} \text { depth. }\end{array}$ & CL & $\begin{array}{c}\text { Waller and Moser 1990, } \\
\text { Della Lucia 1993, Navarrete- } \\
\text { Heredia } 2001 \text { (as accidental) }\end{array}$ \\
\hline Atta & Clytrine & CL & Jolivet 1978 \\
\hline Atta mexicana (F. Smith) & $\begin{array}{l}\text { Pachybrachis sp. On } \\
\text { external ant debris }\end{array}$ & CR & $\begin{array}{c}\text { Márquez-Luna and } \\
\text { Navarrete-Heredia 1994, } \\
\text { Navarrete-Heredia 2001 } \\
\text { (as accidental) }\end{array}$ \\
\hline
\end{tabular}


Table I.Continued.

\begin{tabular}{|c|c|c|c|}
\hline Taxon & Beetle species & Tribe & Source \\
\hline Atta mexicana (F. Smith) & $\begin{array}{l}\text { Griburius sp. (misspelled as } \\
\text { Griburium). On external ant debris, }\end{array}$ & $\mathrm{CR}$ & $\begin{array}{l}\text { Márquez-Luna and } \\
\text { Navarrete-Heredia } \\
\text { 1994, Navarrete-Heredia } \\
\text { 2001(as accidental). }\end{array}$ \\
\hline $\begin{array}{c}\text { Crematogaster lineolata } \\
\text { (Say) }\end{array}$ & Anomoea & CL & Stiefel and Margolies 1998 \\
\hline $\begin{array}{c}\text { Crematogaster lineolata Say } \\
\text { (the ants carries the eggs to } \\
\text { their nest) }\end{array}$ & Anomoea flavokansiensis Moldenke & $\mathrm{CL}$ & Stiefel and Margolies (1998) \\
\hline $\begin{array}{c}\text { Crematogaster mimosa } \\
\text { Santschi }\end{array}$ & Hockingia curiosa Selman & $\mathrm{CL}$ & $\begin{array}{c}\text { Selman 1988, Erber 1988, } \\
\text { Jolivet } 1991\end{array}$ \\
\hline Crematogaster sjostedti Mayr & Hockingia Selman & $\mathrm{CL}$ & Selman 1962 \\
\hline $\begin{array}{c}\text { Crematogaster } \\
\text { (Crematogaster) nigriceps } \\
\text { Emery }\end{array}$ & Isnus petasus Selman & $\mathrm{CR}$ & $\begin{array}{l}\text { Selman 1962, 1988; } \\
\text { Hocking 1970, Jolivet } 1986\end{array}$ \\
\hline $\begin{array}{c}\text { Nest of Crematogaster } \\
\text { peringueyi Emery }\end{array}$ & Clytrine cases & CL & Péringuey (1898) \\
\hline Crematogaster sp. & $\begin{array}{c}\text { Coenobius macarangae Gressitt (living } \\
\text { on myrmecophyte) }\end{array}$ & CR & Jolivet 1991 \\
\hline Crematogaster sp. & $\begin{array}{c}\text { Cadmus macarangae Gressitt (living } \\
\text { on myrmecophyte) }\end{array}$ & $\mathrm{CR}$ & Jolivet 1991 \\
\hline Messor clivorum sevani Kar. & $\begin{array}{c}\text { Clytra (Clytraria) valeriana valeriana } \\
\text { Ménétriés }\end{array}$ & $\mathrm{CL}$ & Medvedev 1962 \\
\hline Messor Forel & Clytra sp. & $\mathrm{CL}$ & $\begin{array}{l}\text { Jolivet and Hawkeswood } \\
1995\end{array}$ \\
\hline Messor barbarus L. & Lachnaia vicina Lacordaire. & $\mathrm{CL}$ & Barbier 1976, Erber 1988 \\
\hline $\begin{array}{c}\text { Messor barbarus capitatus } \\
\text { Latreille }\end{array}$ & Tituboea biguttata (Olivier) & CL & Fiori 1957 \\
\hline Messor spp. & Tituboea biguttata (Olivier) & $\mathrm{CL}$ & Erber 1988 \\
\hline Messor barbarus L. & Tituboea biguttata (Olivier) & $\mathrm{CL}$ & Medvedev 1962, Jolivet 1952 \\
\hline $\begin{array}{c}\text { Messor barbarus capitatus } \\
\text { Latreille }\end{array}$ & Tituboea biguttata (Olivier) & $\mathrm{CL}$ & Medvedev 1962 \\
\hline Messor barbara (L.) & Tituboea Lacordaire & $\mathrm{CL}$ & Barbier 1976 \\
\hline Messor barbara L. & Clytrine & $\mathrm{CL}$ & Barbier 1976 \\
\hline $\begin{array}{l}\text { Mymica rugolosa Nylander, } \\
\text { queen using larval case for } \\
\text { colony founding }\end{array}$ & Cryptocephalus morarei (L.) & $\mathrm{CR}$ & Schöller 1999 \\
\hline $\begin{array}{c}\text { Pheidole sp. Queen with } \\
\text { eggs and workers on larval } \\
\text { case }\end{array}$ & Cryptocephalus anceps Suffrian & $\mathrm{CR}$ & Schöller 1999 \\
\hline Tetramorium caespitum L. & Clytra sp. & $\mathrm{CL}$ & Girard 1873 \\
\hline Tetramorium caespitum L. & Clytra sp. & $\mathrm{CL}$ & $\begin{array}{l}\text { Escherich and Emery 1897, } \\
\text { Jolivet 1952, Medvedev } 1962\end{array}$ \\
\hline Tetramorium caespitum L. & Smaragdina concolor (Fabricius) & $\mathrm{CL}$ & $\begin{array}{c}\text { Xambeu 1899, Medvedev } \\
\text { 1962, Erber } 1988\end{array}$ \\
\hline Tetramorium vespitum $\mathrm{L}$. & Smaragdina concolor (Fabricius) & $\mathrm{CL}$ & Jolivet 1952 \\
\hline Leaf cutting ant nest & Megalostomis dimidiata Lacordaire & $\mathrm{CL}$ & Agrain 2010 \\
\hline
\end{tabular}


Table I.Continued.

\begin{tabular}{|c|c|c|c|}
\hline Taxon & Beetle species & Tribe & Source \\
\hline $\begin{array}{l}\text { Eat detritus and Humus, } \\
\text { associated with ants }\end{array}$ & Anomoea & CL & $\begin{array}{c}\text { Moldenke 1970, Jolivet and } \\
\text { Hawkeswood } 1995\end{array}$ \\
\hline Myrmecophile & Clytra sp. & $\mathrm{CL}$ & Escherich 1899, Erber 1988 \\
\hline Ant eggs & Clytrine & $\mathrm{CL}$ & McAtee 1932 \\
\hline As myrmecophiles & Clytrine & $\mathrm{CL}$ & Jolivet 1952 \\
\hline As myrmecophiles & Clytrine & $\mathrm{CL}$ & Doguet 1992 \\
\hline Dead leaves in ant nests & Clytrine & $\mathrm{CL}$ & $\begin{array}{l}\text { Johnson and Triplehorn } \\
2004\end{array}$ \\
\hline In ant nests & Clytrine & $\mathrm{CL}$ & Jolivet 1991 \\
\hline $\begin{array}{c}\text { Larvae that overwinter as } \\
\text { ant inquilines }\end{array}$ & Clytrine & $\mathrm{CL}$ & $\begin{array}{c}\text { Erber 1988, Steifel et al. } \\
\text { 1995, Jolivet } 1996\end{array}$ \\
\hline Ant host & $\begin{array}{c}\text { Coscinoptera dominicana dominicana } \\
\text { (Fabricius) }\end{array}$ & $\mathrm{CL}$ & $\begin{array}{c}\text { Riley 1882, Wasmann } \\
\text { 1894a, Van Dyke 1925, } \\
\text { Wickham } 1896\end{array}$ \\
\hline Ants on Acacia tolerate ants & Cryptocephaline & CR & Jolivet 1996 \\
\hline Ant nests & Cryptocephalus Geoffroy & CR & $\begin{array}{l}\text { Donisthorpe 1927, Kasap } \\
\text { and Crowson } 1976\end{array}$ \\
\hline Ant host & Helioscopa Gistel & $\mathrm{CL}$ & $\begin{array}{l}\text { Jolivet and Hawkeswood } \\
1995\end{array}$ \\
\hline $\begin{array}{l}\text { Associated with ants, } \\
\text { myrmecophiles, or } \\
\text { submyrmecophiles }\end{array}$ & Labidostomis Chevrolat in Dejean & $\mathrm{CL}$ & $\begin{array}{c}\text { Jolivet 1952, 1978; Selman } \\
\text { 1988, Erber } 1988\end{array}$ \\
\hline $\begin{array}{c}\text { As obligate or facultative } \\
\text { ant inquilines }\end{array}$ & Lachnaia Chevrolat in Dejean & $\mathrm{CL}$ & Erber 1988 \\
\hline Myrmecophilous larvae & Lachnaia italica italica Weise & $\mathrm{CL}$ & Regalin et al. 2006 \\
\hline $\begin{array}{l}\text { Found in the vicinity of } \\
\text { ant nest) }\end{array}$ & Macrolenes dentipes Olivier & CL & Schöller 1998 \\
\hline As myrmecophiles & Megalostomis Chevrolat & CL & $\begin{array}{c}\text { Jolivet and Hawkeswood } \\
1995\end{array}$ \\
\hline $\begin{array}{l}\text { Found in the vicinity of } \\
\text { ant nest) }\end{array}$ & Pachybrachis anoguttatus Suffrian & $\mathrm{CR}$ & Schöller 1998 \\
\hline In ant nests & Saxinis (Boreosaxinis) saucia LeConte & $\mathrm{CL}$ & Van Dyke 1925, Hatch 1971 \\
\hline
\end{tabular}

\section{Discussion}

Since most records found in the extant literature are the product of a chance finding of the beetles in association with the ant nests, and not of a directed search, it not clear how widespread ant associations really are. Below we discuss some patterns of ant associations we recognized in our synthesis. The study of myrmecophilous beetles have has revaled an extraordinary amount of adaptations (Mynhardt 2013), therefore, further research on other beetle lineages may provide useful touchstones to guide theoretical or empirical research on cryptocephaline myrmecophily.

Quality of available data. Records of myrmecophilous species summarized in Table 1 have accumulated over the last 180 years since Chevrolat (1835) first reported a crypto- 
1

A
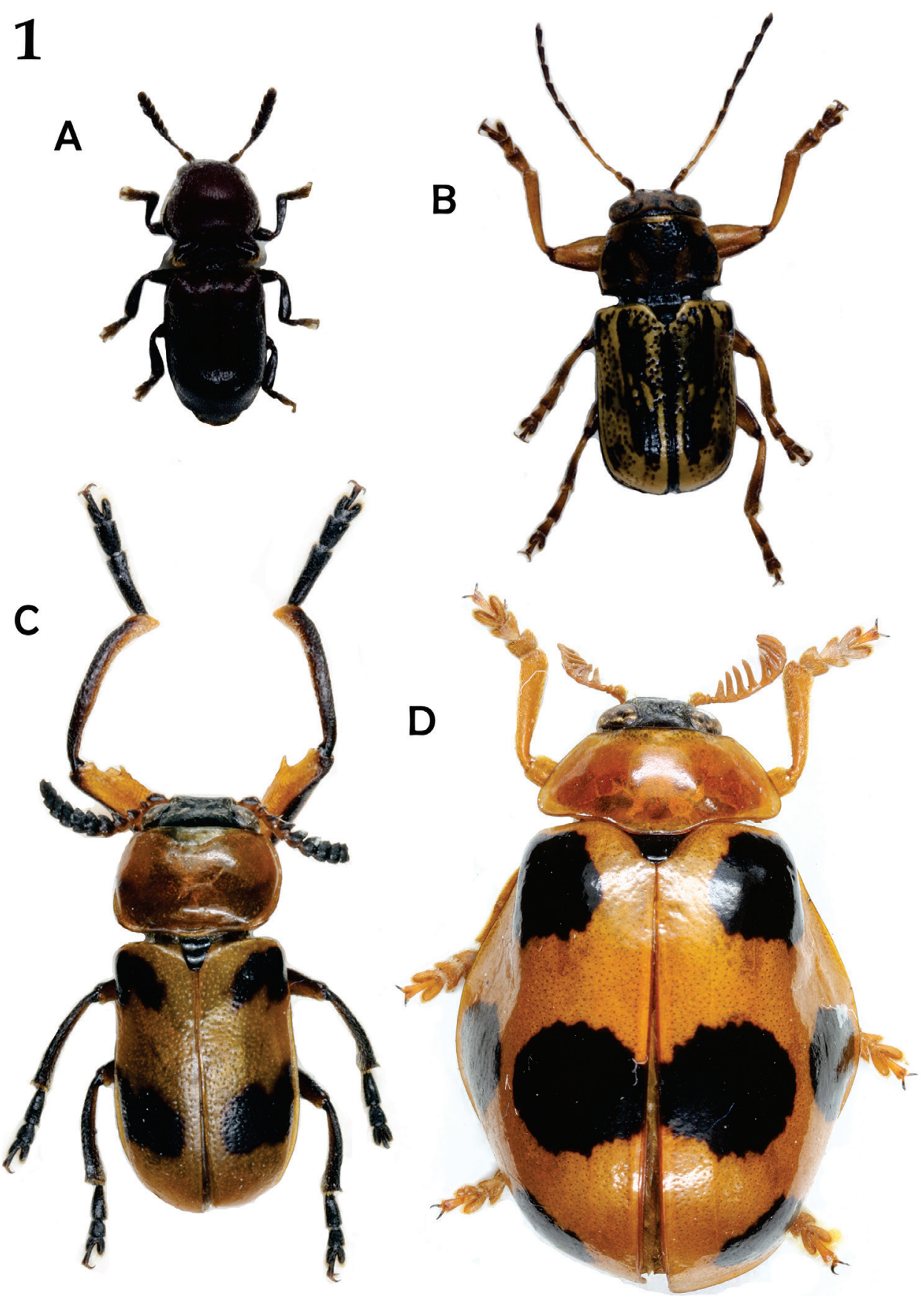

Figure I. Some Cryptocephalinae associated with ants; A Hockingia curiosa Selman B Pachybrachis pallidulus Suffrian C Macrolenes dentipes (Olivier) D Clytrasoma balyi Monrós (not to scale). Photos: Matthias Schöller. 

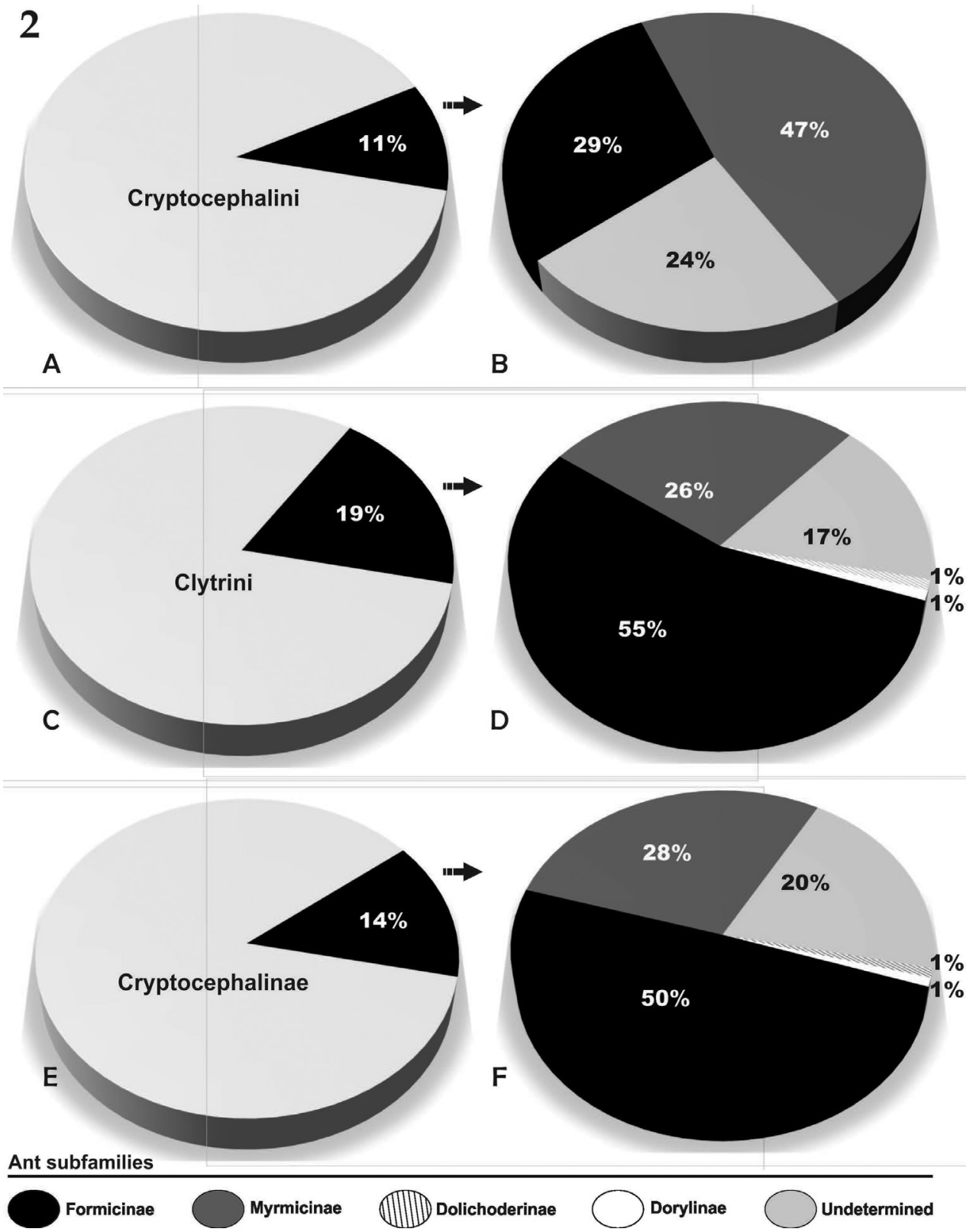

Figure 2. Ant association records. Each pie chart indicates ant association records expressed as percentages, different color tones refer to each ant subfamilies as indicated in the color reference below: A-B records within the tribe Cryptocephalini C-D records within the tribe Clytrini E-F records within the whole subfamily.

cephaline-ant association. We believe a collection bias exists in these data. For instance, some ant nests are the focus of a great deal of study and subsequent excavation (e.g. Atta nests); these species would, as a result, have more records of myrmecophilous species 
Table 2. The number of Cryptocephalinae genera associated with ant hosts.

\begin{tabular}{c|c|c}
\hline Tribe / Genus & Myrmecophilous species number & Number of ant genera recorded as host \\
\hline Clytrini & & $2+$ undet. \\
\hline Anomoea Agassiz & $1+$ undet. & $7+$ undet. \\
\hline Clytra Laicharting & $4+$ undet. & 1 \\
\hline Clytrasoma Jacoby & 1 & $2+$ undet. \\
\hline Coscinoptera Lacordaire & 2 & undet. \\
\hline Helioscopa Gistel & undet. & 2 \\
\hline Hockingia Selman & $1+$ undet. & $1+$ undet. \\
\hline Labidostomis Germar & $1+$ undet. & $2+$ undet. \\
\hline Lachnaia Chevrolat & $1+$ undet. & undet. \\
\hline Macrolenes Chevrolat & 1 & undet. \\
\hline Megalostomis Chevrolat & $2+$ undet. & 1 \\
\hline Saxinis Lacordaire & 1 & 3 \\
\hline Smaragdina Chevrolat & 1 & $5+6$ undet. \\
\hline Tituboea Lacordaire & $3+$ undet. & $1+$ undet. \\
\hline Undetermined & 11 & 1 \\
\hline Cryptocephalini & & 1 \\
\hline Cryptocephalus Geoffroy & $1+$ undet. & 1 \\
\hline Cadmus Erichson & 1 & $2+$ undet. \\
\hline Coenobius Suffrian & 1 & $1+$ undet. \\
\hline Griburius Haldeman & 1 undet. &
\end{tabular}

inhabiting them than other ant nests that are more difficult to study (e.g. Dorylus) or simply understudied. Verifying the accuracy of host records presented here has not been our primary goal, so some records presented here may not hold up to future scrutiny and/or data (through additional fieldwork and/or examination of museum vouchers). Finally, some species of cryptocephalines have received more study than others, and hence, their host patterns are not in common with other species. For instance, the Palearctic Clytra (Clytra) quadripunctata is one of the most studied cryptocephaline species, and has consequently been recorded from ant nests of 12 species within 3 genera in 2 different subfamilies. If more fieldwork were conducted on all myrmecophilous cryptocephaline species, the pattern of host use might be very different.

Taxonomic patterns of host use. All records examined here indicate that myrmecophilous cryptocephalines are specialists on the formicoid ants, a branch of Formicidae, which include the most common ant species as well as the major invasive species (Brady et al. 2006). The sister-group to the formicoids, the poneroid clade, does not appear to be exploited by cryptocephalines. This formicoid clade has been estimated to range between 105-120 mya (Brady et al. 2006) and 107-119 (Moreau and Bell 2013), but the subfamilies and genera of interest to this study are much younger, and will be covered below. 
The most striking pattern that emerges from the assembled data relates to Clytra. Members of this genus have the broadest host range, with records from some of the more core formicines such as the carpenter ants (Camponotus) and Formica ants, but also from the myrmicines Aphaenogaster, Messor, and Tetramorium. While many species of Camponotus and Formica can be found commonly in forested environments (and often, in fact, co-occur), species of Messor are found in more xeric environments, and are herbivorous, seed-harvesting ants (the former are generalist predators). However, Brady et al. (2006) estimated the root-nodes of formicines and myrmicines to be roughly 77-82 mya, and concluded these two subfamilies are sister-groups of each other. Moreau and Bell (2013) recovered the root node of formicines at between 74.9 and 90.3 mya, and myrmecines between 79.3 and 89.8 mya; this study did not recover the two subfamilies as sister-groups, but instead found ectatommines and heteroponerines nested between the two families (but lacking branch support). Today cryptocephalines are associated with both the formicines and myrmecines. Within Clytra, we see some degree of host specificity, exemplified by Clytra (Clytra) laeviuscula having an affinity for species of Lasius, Clytra (Clytra) quadripunctata being associated with species of Formica, and Clytra (Clytraria) atraphaxidis being recovered only from species of Cataglyphis (Table 1). This last observation suggests that something of the ant's defensive behavioral profile or chemical profile (or both) have been exploited by these beetles, and through this exploitation, a certain degree of evolutionary canalization has taken place. Otherwise, we would likely see a plethora of generalist beetles exploiting all manners of ant subfamilies; the data herein reported do not support that hypothesis.

Below we summarize some of the broad challenges of myrmecophily mentioned above (see (Hölldobler and Wilson 1990). Myrmecophilous cryptocephalines appear to use different strategies to live near, enter, or inhabit ant nests. The following discussion analyzes the quality of data available for each challenge posed by the ants' welldefended fortress.

1) Finding the host ant. In some Clytrini, the female oviposits on a leaf and drops the egg, after being intricately covered by feces, to the ground. Ants then carry the eggs, or the first instar larvae within its fecal case, inside the nest (Jolivet 1991, Schöller 2011). Some egg cases are attached to the substrate by a peduncle; Jolivet and Petitpierre (1981) mentioned that ants cut the peduncle in those cases. They also remark that 'naked' eggs, i.e. lacking a case, are eaten by the ants.

2) Living outside the nest. Some species have been found on external ant debris and are known to feed on it. The biologic meaning of this have not yet been studied, it might be that debris is a rich food source, or possibly, it provides the beetle or larvae with some sort of camouflage.

3) Trail following. Jolivet (1952) mentioned that Clytrini larvae follow the migrations of the nomadic Dorylus ants (army ants, Formicidae: Dorylinae) during day or night, and that the clytrine adults interact with ants near or inside the nest. This sug- 
gests that in some cases, all life stages of camptosomates are capable of interacting with ants. In the case here, the presence in the adults of deep grooves for the reception of appendages (such as antennae and legs) and the cryptic nature of the presence of their head within the prothorax, suggests this to be true.

4) Entering the ant nest. All myrmecophiles must enter and remain in the ant nests without being expelled or killed (Hölldobler and Wilson 1990, Lenoir et al. 2001). The inquiline must be adopted, or at least tolerated inside the nest, and this is usually accomplished by chemical mimicry [e.g. Trichopsenius Horn (Coleoptera: Staphylinidae) inside Reticulitermes Holmgren nests (Isoptera: Rhinotermitidae) (Lenoir et al. 2001, and references therein)]. Erber (1988) indicates that Hockingia curiosa might live obligatorily in ants nest, the genus mimics the body form of Crematogaster ants in Tanzania. The adults exhibit interesting myrmecophilous organs, which consist of two setae bearing tubercles on the pronotum (Fig. 1A), possibly with a secretory function. Isnus petasus also bears long setae on the lateral pronotal margins (Selman 1962). Secretory hairs or bristles and special glands (e.g. adoption glands sensu Hölldobler 1970 or defense glands) are not uncommon in myrmecophilous insects (Hölldobler and Wilson 1990) and they may discharge mimicking, appeasing, tranquilizing, repellent or deadly chemicals. Detailed anatomical and scanning electron microscopy might reveal such organs in Cryptocephalinae and chemical analysis will reveal the nature of the exudates. Cryptocephaline adults studied thus far bear a paired basolateral seta on the pronotum.

5) Evolution towards living and surviving in ant nests. Once inside an ant nest, whether temporarily or long-term, every myrmecophile is faced with new challenges, from avoiding being detected as an enemy, to finding a safe micro-habitat within the ant complex, to finding food, and carrying on its life cycle.

5a) Avoiding being eaten by ants. Cryptocephalinae adults exhibit some typical chrysomelid defenses - chemical sequestration and secretion of toxic compounds (e.g. reflex bleeding) (Selman 1988), mimicry (Hespenheide 1999), defensive stridulation (Monrós 1953, Schmitt 1994), thanatosis (Monrós 1953, Selman 1988), aposematic coloration (Selman 1988, and references therein), gregarious behavior (Monrós 1953); and, as mentioned above, at least some species are thought to have complex myrmecophilous organs (Selman 1988). Egg, larval and pupal cases provide physical protection against predators (Wallace 1970, Root and Messina 1983, Schöller 2014). Furthermore, they are also cryptic and work as a barrier against desiccation, this last function being important as it has been observed that camptosomates are relatively more sensitive to desiccation than other chrysomelids (Root and Messina 1983). The larval cases are sometimes armored with plant trichomes (Chaboo et al. 2008). Camptosomata that develop within the ant nest have to leave it as adults, and are consequently faced with attacks by ants. Species that develop in the vicinity of the nest may be attacked as well. Clytra (Clytra) laeviuscula responds with thanathosis when attacked by ants and 
when the ants lose interest in the beetle, it walks away or flies off quickly. The adults of Labidostomis taxicornis and Lachnaea pubescens do not exhibit thanathosis; instead, they move quickly to avoid being attacked, and typically do not survive the ant attacks if caught (Schöller pers. obs.). Nevertheless, defense or antipredator devices of the larvae against ant attacks largely remain unknown.

5b) Avoiding other dangerous organisms in the ant nest. In reports of associations with ants, hymenopterans are the most frequent parasitoids of eggs and larvae of the Camptosomata (Erber 1988). Bethylidae wasps are known specialized parasitoids of coleopteran larvae (Evans 1964); many bethylid females are wingless, and their small size and flat body allow them to locate prey in hard-to-access places, such as ant nests. Nagy (1969) found the bethylid Mesitius horvathi Kieffer attacking a clytrine. Mutillids (velvet ants; Mutillidae) were also found to attack the enclosed larvae or pupae of species of Coleoptera, including some cryptocephalines (Lawrence and Britton 1991) that live in the ant nests (Brothers et al. 2000). Brothers (1975) could not trace a parallel between the evolution of the mutillids and that of their hosts, so colonization of new hosts is likely a common pattern. Mutillids are thought to have evolved from parasitoids of ground-nesting Hymenoptera, however, host fidelity is not high and host-shifts to distantly related hosts (even in different orders) have apparently occurred. Brothers et al. (2000) indicate that more host records of mutillids parasitizing Clytrini are expected to be found, while the occurrence of Cryptocephalini species as hosts of mutillids in association with ants need to be confirmed. The larvae of mutillid wasps may be parasitoids of host stages which are enclosed in some sort of "hard" package and which are not actively feeding (Brothers 1972, 1989). In ant associations, the well-known occurrences of mutillids always involve parasitism of chrysomelid beetles living in the ant nests and having hard cases. It is unknown whether other mutillid species attack ants directly.

Within the proctotrupomorph Hymenoptera (most of the formerly recognized superfamilies of Parasitica; Sharkey et al. 2007) are a number of ant-specialist lineages. The Universal Chalcidoidea Database (Noyes 2015) cites just under 700 parasitic chalcidoid species that have been recorded from Chrysomelidae; among these species, five have been recorded from Cryptocephalus, and none from the other myrmecophilous genera covered herein. Within Ichneumonoidea, 77 genera and over 200 species are known parasitoids of chrysomelids, with 7 species of Cryptocephalus recorded as hosts (Yu et al. 2012), including Gelis acarorum (L.) and Dimophora evanialis Gravenhorst (Schöller 1999). Together with members of the aculeate Bethylidae and Mutillidae, the parasitoid pressure on cryptocephalines to escape parasitism is rather high, and utilizing a refugia such as an ant nest would release the parasitoid pressure significantly on these beetles.

5c) Microhabitat specialization within the nest and diet: An ant nest presents multiple places to live, including open chambers, refuse heaps ("kitchen midden"), brood chambers or nurseries (heavily defended but high-quality food), and fungus gardens 
for those ants that cultivate fungi. Presently it is unknown where cryptocephaline myrmecophiles live within the ant nest. Some of these sites can offer different degrees of protection and different resources to exploit, yet nothing is known about the selection mechanism employed by myrmecophilous cryptocephalines among the different nest chambers. The only insight may be provided by the relation between the food inside the ant nest and the diet of the beetle larvae. Leaf beetles show a general pattern of adults and larvae living on the same host plants. However, some cryptocephalines show a further distinction where the larval and adult stages can have different habitats and diet; this is particularly true for Clytrini and Cryptocephalini. Some species have zoosaprophagous and phytosaprophagous larvae (Schöller 1998). The myrmecophilous larvae appear to feed on ant droppings and pellets (Erber 1988; Lapeva-Gjonova 2013); others feed on detritus (LeSage 1985, 1986; Erber 1988, Stiefel 1993), leaf litter or dead insects collected by the ants (Schöller 1998); or, on ants or ant bodies (Riley 1882). Schöller (1995) posits that zoosaprophagy may be an important aid for the development of larvae inhabiting arid and semi-arid regions, when plant foliage is scarce. Even if some interactions between ants and their associates are known (i.e. social parasitism), the precise behavioral characters and payoffs are not so clear. It is believed that most of the nest associates take advantage of the nest micro-habitat, living as commensals on dead ants and assorted detritus from the ant fungus garden (Waller and Moser 1990).

Fungi inside an ant nest can provide food or can pose a threat to cryptocephalines. Ants such as the Attini (the leafcutter ants) cultivate fungi and these fungus gardens may provide both a micro-habitat to live in and a larder of food. Fungi are commonly known to negatively affect immature stages of cryptocephalines. Yet, there is only one formal citation by Jolivet and Theodorides (1952) of the fungus Sporotrichum sp. affecting the larvae and pupae of Clytra (Clytra) quadripunctata; currently it is impossible to know the specificity of this relationship. Fungal mycelia appear to be part of the case construction (Chaboo et al. 2008).

6.) Benefits for the host? Although no chemical recompense is known to be offered by myrmecophilous cryptocephalines, Schöller (1999) found empty larval cases of Cryptocephalus species being used as microchorions by certain Formicidae and Aranae. Yet more remarkable, Schöller (1999) also found queens of Myrmica and Pheidole using cases as a place for colony founding, which indicates that these myrmecophilous systems are rather complex and may be synergistic. However, it should be noted that most strategies of cryptocephalines to enter, reside and leave the ant nests remain largely undocumented.

Strength of host association. The strength of myrmecophilic relationships can vary, as some larvae can survive without actually entering an ants' nest (Erber 1988, and references therein). Within clytrines, adults of Hockingia exhibit an extraordinary morphology indicative of a strong integration with ants; yet, when considering the larvae or pupae, they seem to exploit a protective strategy, solely relying on the protection 
offered by their cases and a plug-like head. Important evidence to solve this problem might come from the study of known or new myrmecophilous organs, present in camptosomate beetles that would provide appropriate compensation for the ants. Nevertheless, according to present evidence, it is possible to find a plethora of relationships, from mutualism to parasitism. Below we introduce some interesting aspects of the evolutionary challenge faced by cryptocephalines living with ants.

The reports to date suggest some degree of specialization in non-Clytra species. Megalostomis dimidiata is an Atta specialist; Anomoea, Clytrasoma (Fig. 1D), Hockingia (Fig. 1A), and Isnus petasus are all Crematogaster specialists; Tituboea biguttata are harvester ant (Messor) specialists; and Smaragdina concolor (Fabricius) are known from the pavement ant Tetramorium. With respect to these ant species, some aspects of their biology may help explain this degree of specificity. Both Atta and Messor have longlived nests, in that they typically remain in one location for several years (Hölldobler and Wilson 1990), and this is largely afforded by having a nearly constant source of food (fungus in the case of Atta; seed caches in the case of Messor). This sort of stable environment could allow for long-term myrmecophilous relationships to evolve, and in fact, Atta species typically harbor a large number of commensal species living among their nests (Waller and Moser 1990). It is also quite intriguing considering that the root node of Atta has been estimated to be some 8 my old, more or less a newcomer in evolutionary time, which means its inquiline (Megalostomis dimidiata) is likely to be even younger than that.

Regarding the strength of currently known Cryptocephalines/ants associations, Selman (1988) sorted the life histories of the following assemblages: Clytral Formica, and Hockingia, Isnus/Crematogaster as cases of commensalism, or perhaps parasitism. The author also remarked the importance of the stable temperature within the ant nests as a clear advantage for cryptocephalines. Hitherto, even if these are the most studied cases, we do not know much about the organisms.

Another unusual pattern to emerge from our synthesis is the case of Dorylus, a genus that includes army ants, which do not construct a typical ground nest like many other formicids, but instead, a bivouac as needed, and remain constantly in search of prey items (Hölldobler and Wilson 1990, and references therein). Jolivet (1952) offers a very intriguing observation of an unidentified Clytrini whose larvae migrates with a Dorylus species; how a relationship such as this can evolve is quite fascinating, but certainly requires further verification beyond this single reference. Labidostomis taxicornis is the only known cryptocephaline to be associated with a Dolichoderinae (Tapinoma erraticum). Dolichoderines are some of the most notoriously invasive species of ants (entering non-native habitats/regions), with species such as T. sessile and $T$. melanocephalum essentially found worldwide. Considering the commonality of $T a$ pinoma species, it is reasonable to expect that we would have recorded more cryptocephalines from this group of ants by now if the species actually existed. This dearth of cryptocephaline species associated with such a common, widespread group suggests the relationship between Labidostomis taxicornis and Tapinoma erraticum is something unique. This may also apply to Smaragdina concolor, which has been associated with 
the highly invasive pavement ant (Tetramorium caespitum). In this case, it would be fascinating to conduct additional fieldwork to determine if the beetle has been able to track its host ant into novel geographic regions, or if it is restrained to the aboriginal home of the ant.

Summarizing, existing evidence indicates multiple routes to myrmecophily in cryptocephalines, even if adults are above-ground herbivores and occasionally interact with ants; their immature stages (eggs, pupae and larvae) are the most exposed stages in terms of ant interaction. Myrmecophilous cryptocephalines can be found in subterranean (e.g. Megalostomis larvae found at $2.5 \mathrm{~m}$ inside Atta nest), arboreal (e.g. Isnus in Acacia ant nests), and terrestrial (e.g. Pachybrachis on external debris of Atta nests) habitats.

Geography of ant association (Table 3). While the origin of myrmecophily is thought to be monophyletic among Old World genera of Clytrina (Schöller and Witte 2007), it is currently unknown if myrmecophily was inherited or newly acquired by $\mathrm{New}$ World cryptocephalines. To date, only two genera of Cryptocephalini have been cited as myrmecophilous in the New World. So far, no records of beetle/ant association have been found for Australian, Madagascan, Oceanian, Oriental, Papua-Melanesian, and Sino-Japanese regions (sensu Holt et al. 2013) (Fig. 3). The most remarkable specialized ant interactions known today (i.e. involving complex myrmecophilous organs and myrmecomorphy) are known for the Afrotropical region: Clytrini (Hockingia) and Cryptocephalini (Isnus), both genera related to Crematogaster ants. It is interesting to remark that Crematogaster is almost globally distributed today, and have apparently achieved this large distribution range by successive dispersion events since their origin in the mid-Eocene (Blaimer 2012). Actually, in most cases, the ants that have been

Table 3. Genera of Cryptocephalinae by region and ant subfamily. Note all genera belong to the tribe Clytrini except for those marked with $\left({ }^{*}\right)$, which belongs to the Cryptocephalini.

\begin{tabular}{|c|c|c|c|c|c|}
\hline Region & Formicinae & Myrmicinae & Dolichoderinae & Dorylinae & Undet. \\
\hline Afrotropical & Hockingia & $\begin{array}{c}\text { Hockingia, } \\
\text { Isnus }^{*},+ \text { undet. }\end{array}$ & - & Undet. & - \\
\hline Nearctic & $\begin{array}{c}\text { Anomoea, } \\
\text { Coscinoptera }\end{array}$ & $\begin{array}{l}\text { Anomoea, } \\
\text { Megalostomis }\end{array}$ & - & - & $\begin{array}{l}\text { Anomoea, } \\
\text { Coscinoptera, } \\
\text { Lachnaia, } \\
\text { Megalostomis, } \\
\text { Saxinis }\end{array}$ \\
\hline Neotropical & $\begin{array}{l}\text { Megalostomis, } \\
\text { Pachybrachis }\end{array}$ & $\begin{array}{c}\text { Megalostomis, } \\
\text { Griburius** }\end{array}$ & - & - & Helioscopa \\
\hline Oriental & Clytrasoma & & & & \\
\hline Palearctic & $\begin{array}{c}\text { Clytra, } \\
\text { Cryptocephalus*, } \\
\text { Lachnaia, } \\
\text { Pachybrachis*, } \\
\text { Tituboea, + undet. }\end{array}$ & $\begin{array}{c}\text { Clytra, } \\
\text { Smaragdina, } \\
\text { Tituboea }\end{array}$ & - & - & $\begin{array}{c}\text { Clytra, } \\
\text { Macrolenes } \\
\text { Cryptocephalus*, } \\
\text { Lachnaia } \\
\text { Pachybrachis* }\end{array}$ \\
\hline $\begin{array}{l}\text { Saharo- } \\
\text { Arabian }\end{array}$ & Clytra & $\begin{array}{r}\text { Lachnaia, } \\
\text { Tituboea } \\
\end{array}$ & Labidostomis & - & - \\
\hline
\end{tabular}




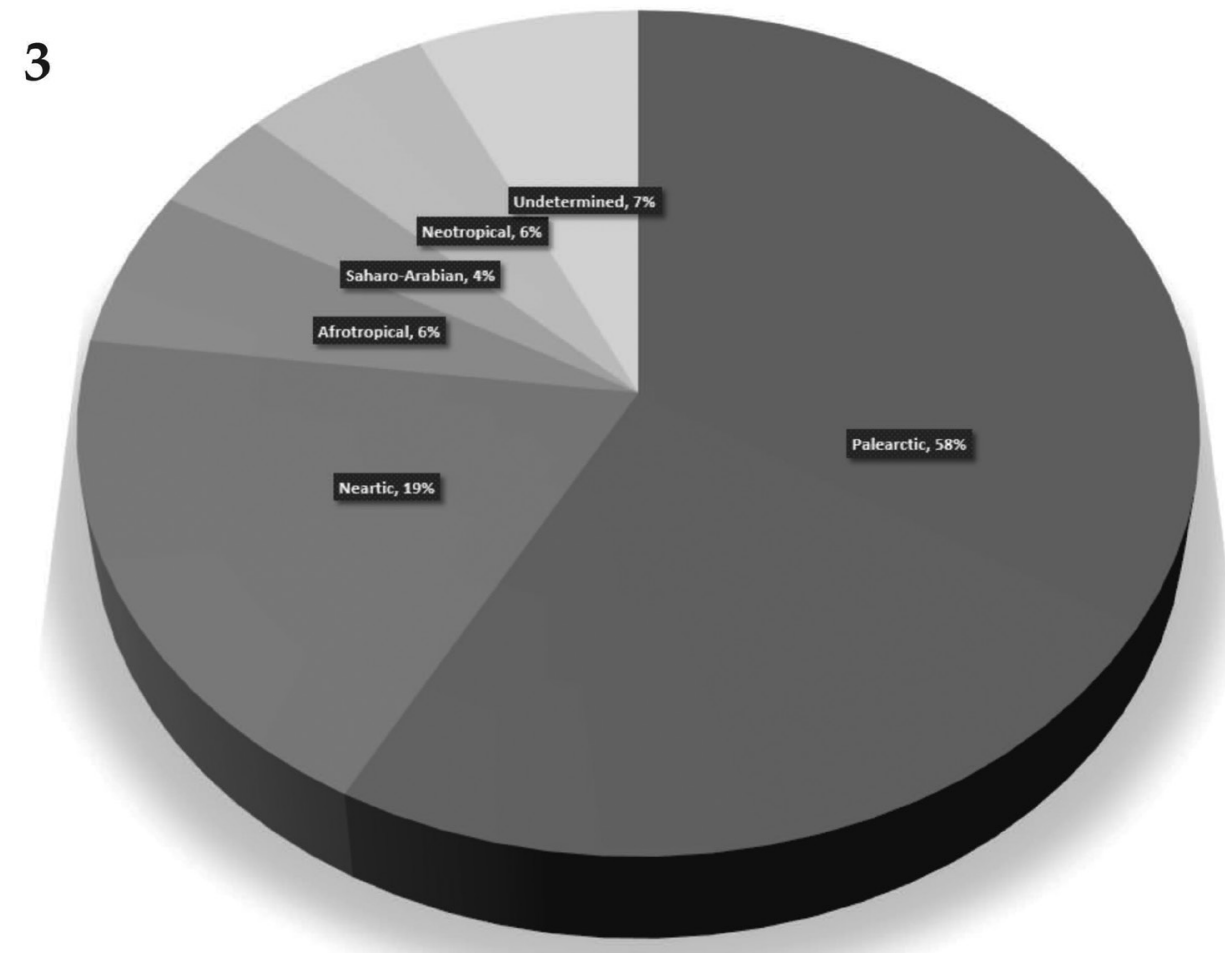

Figure 3. Ant association records by region. The percentage values indicates the fraction of ant association records known for each zoogeographic region.

associated with cryptocephalines are widely distributed, which suggests further records of myrmecophily are to be found for the also widely distributed cryptocephalines. The latter being especially true for the Neotropical region, which is mostly unexplored for myrmecophilous cryptocephalines, despite of its richness in endemic species and genera of ants (Holdobler and Wilson 1990), particularly in the tribe Attini. Finally, some other interesting patterns have been revealed in this study that require further investigation: although there is no myrmecophilus cryptocephaline recorded in Australia, there are three ant genera there that do host cryptocephalines in other parts of the world; even though the species of the dolichoderine Tapinoma are cosmopolitan, there is only one extant record for the genus.

\section{Calibrating the evolutionary history of ants and Camptosomata}

Wilson and Hölldobler (2005) pointed out three major events in the evolution of ants: 1) early radiation during mid-Cretaceous aided by complex ground litter (angiosperms assembled); 2) a dominance of ants in the angiosperm-rich tropical forests during the Paleogene; and 3) diet shift events in the dolichoderines, formicines, and certain myr- 
micines. These events triggered expansion from tropical forest and general predation, into the canopy and into xeric environments and more specialized feeding behaviors.

According to Brady et al. (2006) myrmecines and formicines are sister-groups, and they split around 75-84 mya (but see Moreau and Bell 2013), and some of them exploit symbiotic relationships. This evolutionary picture favors the scenario for the acquisition of myrmecophily in casebearer species and a date of origin in the upper Cretaceous. The older fossil evidence of cryptocephaline larvae (in their cases) include specimens in Dominican Miocene (20 mya) and Baltic (45 mya) ambers (Grimaldi and Engel 2005, Chaboo et al. 2009, Bukejs and Chamorro 2015), thus the minimum age of case-bearing behavior dates to 45 mya. This data is compatible with Wang et al. (2014), yet it differs from other studies on leaf beetles phylogeny (i.e. Hunt et al. 2007, Gómez-Zurita et al. 2007), which date the origin of Chrysomelidae and Cryptocephalines much later.

Table 2 clearly shows that nearly all of the known records of myrmecophily in the cryptocephalines belongs to the Myrmicinae + Formicinae clade, whose common ancestor date from Mid-Cretaceous, 125-75 mya (Brady et al. 2006, Moreau et al. 2006, Geiselhard et al. 2007). The Dolichoderinae clade has an estimated origin of 65 mya (Ward et al. 2010), and the tribe Tapinomini seems to have originated in the Paleotropics. Ergo, host ants might have been available early during the evolution of Cryptocephalinae, a lineage that began its diversification about 93 mya (Wang et al. 2014).

The evolutionary history of formicoid ants date back to the Upper Cretaceous period (Brady et al. 2006, Moreau and Bell 2013), with genus-level divergences being established later in the Eocene, 50-35 mya; this is also supported by their common presence in amber fossils (Grimaldi and Agosti 2000, Moreau et al. 2006, Dunn et al. 2007, Grimaldi and Engel 2005, LaPolla et al. 2013). Furthermore, the origins of myrmecochory (seed dispersal by ants) were also being established at this same time period (Dunn et al. 2007), which include the associations with Formicinae and Dolichoderinae, and the so called tree-loving ants (Crematogaster) which are well known canopy-dwelling herbivores (Rico-Gray and Oliveira 2007). Leaf-cutting Attini are far more recent, about 7-16 mya (Schultz and Brady 2008). Attines are limited to the New World, and most of the 12 genera and 190 species occur in the tropical portions of Mexico, Central and South America (Hölldobler and Wilson 1990). These ants form large, mature colonies with great diversity of myrmecophilous species. Certain leaf-cutting ants, such as species of Atta, house a large number of "nest guests", for which interactions with the host (ants) are poorly understood (Waller and Moser 1990). The sophisticated habit of culturing and eating fungi by these fungus-growing ant species has evolved in other insects groups as Macrotermitine (termites) and certain wood-boring beetles. So far no case of termitophily has been reported for Cryptocephalines; further, termitophily has been regarded as extremely rare and accidental for Chrysomelidae in general (Jolivet and Petitpierre 1981). According to Korb (2008), social evolution was independently acquired by ants and termites lineages, the author remark that one of the major differences is that termites do not depend on food provisioning activities for their hemimetabolous brood; contrariwise ants has become 
excellent food providers in order to feed their brood. The latter might be thought as a key innovation in ant evolution, which might have driven the origin of myrmecophily within Cryptocephalines searching for food and shelter in ant nest. In this regard, we hypothesize that the nature of food items available inside the termite nest, as well as the effectiveness of the termite defense mechanisms (Puker et al. 2015, and references therein) might explain the absence of termitophily in Chrysomelidae, a relationship which has in fact been exploited by other lineages of Coleoptera as Elateridae, Passalidae, Melyridae, Scarabaeidae, Tenebrionidae, and Carabidae (Costa and Vanin 2010).

A parallel can be traced between the evolution of ants and cryptocephalines regarding climatic preferences. As mentioned above, the last major evolutionary event in ant evolution, according to Wilson and Hölldobler (2005), was the invasion into the canopy niche, aided by diet shift that allowed certain ant groups to colonizing xeric environments. A similar process can be inferred for the diet shift already discussed above in myrmecophilous casebearers: although extant evidence indicates that these might have occurred simultaneously, the precise interconnection of these processes need to be further analyzed to conclude what sort of evolutionary process predominates in such system. Taking Clytrini as an example, most species are characterized as inhabiting temperate, xeric regions (Lopatin 1999). Furthermore, Agrain and RoigJuñent (2011), based on new and previous evidence, hypothesized a tropical/subtropical origin for this tribe. According to Cloudsly-Thompson (2001), the Tenebrionidae and, to a lesser extent, the Chrysomelidae, are among the most successful animals of xeric environments, and species of these groups are often the only ones to be seen atlarge during the day. Jolivet (2004) analyzed adaptations of Chrysomelidae to xeric regions and he mentioned some potential adaptations of clytrines, such as omnivorous larvae, polyphagous adults, lack of potential competitors (i.e. the author mentions that less than $2 \%$ of Chrysomelids live in arid zones), and finally, ant-host protection in subterranean nests (microclimatic, hygienic, and enemy-free space). Schöller (1995) also proposed, as an adaptation to xeric environments, the use of the rectal sclerites as water retention organs. This is a morphological trait exhibited only by the females, and not being shared by males. However, males are short-lived compared to females in many insect species, consequently male longevity may not be adaptive. Moreover, the oviposition process may require a more sophisticated water retention mechanism for the females. We have also observed that most species within the subtribe Megalostomina have thicker elytra (relative to other clytrines in the Neotropical region), such as Anomoea or Lachnaia; this might help in water retention, in a similar way as the subelytral cavity in Tenebrionidae and some other beetles adapted to arid environments (Cloudsly-Thompson 2001 and references therein). Also, Monrós (1953) mentions that adults of Megalostomis gazella Lacordaire rest for periods during daytime, and this, together with the subterranean habits of the larvae, might be an adaptive means for living in climatic extremes.

Key evolutionary steps in Camptosomata. Case-bearing and its correlated behavioral and morphological characters are a complex synapomorphy distinguishing the clade Cryptocephalinae + Lamprosomatinae within Chrysomelidae. It is the most obvious 
defense mechanism of these immature stages (Poinar 1996) and represents a fundamental evolutionary step within leaf beetles. The habitat shift from living in plants to living inside arboreal or subterranean ant nests is an extraordinarily complex problem. A comprehensive phylogenetic analysis of Camptosomata currently underway by a team of researchers, including a number of authors of this paper, hopes to shed some light on the evolution of the group.

Recently, Parker and Grimaldi (2014) described the earliest known specialized myrmecophile, a rove beetle (Staphylinidae) that dates to the early Eocene (52 mya). This indicates that myrmecophily is an ancient evolutionary phenomenon. The detailed study of fossil larval morphology in Cryptocephalines might also provide evidence of specialized morphology indicative of myrmecophily behavior and it would establish a minimum age for myrmecophily within cryptocephalines. Yet, even though the immature stages of cryptocephalines have been studied (Chamorro 2014b, and references therein) and are well preserved in amber fossils, no data on possible myrmecophily specialized structures or chemical substances are currently known.

\section{Conclusions}

Unraveling the evolutionary patterns of the habitat and diets shift in adults and larvae, as well as understanding, the multiple behavioral and morphological adaptations of antloving cryptocephalines will require extensive field work and inter-disciplinary approaches. The relationship with ants suggests the acquisition of ethological and morphological characters that are currently poorly studied. Some basic research activities include: field observations; experiments using artificial ant nests; and detailed morphological studies of the adults and immature stages. Also, the study of the degree of the association (facultative vs. obligate), the effects of this association on host plant choice (i.e. tropic selection mediated by ants), and the possibility of linked cladogenesis between ants and cryptocephaline phylogeny and diversification. Cost-benefit analysis will evaluate the role of each member in an association. Description of life cycles, as well as detailed anatomical studies of all stages are necessary, especially the study of myrmecophilous organs and the possible chemical cues involved. The behavioral, morphological, and chemical adaptations of cryptocephaline myrmecophiles are promising areas for further research.

\section{Acknowledgments}

This research was supported by the authors' respective institutions. Agrain is grateful to CONICET for continued research support and Agencia Nacional de Promoción Científica y Técnica, Argentina (ANPCyT) for additional support to compete this work by PICT\#2013-2211, and PICT\#2011-2573. Chaboo is supported by the University of Kansas. Buffington and Chamorro are supported by the Systematic Entomology Laboratory, ARS-USDA. We are pleased to dedicate this paper to our esteemed col- 
league and chrysomelid researcher, Dr Pierre Jolivet, who has spent his professional career promoting knowledge of leaf beetles, including the relations of leaf beetles and ants. Mention of trade names or commercial products in this publication is solely for the purpose of providing specific information and does not imply recommendation or endorsement by the USDA. USDA is an equal opportunity provider and employer.

\section{References}

Agrain FA (2010) Systematic revision of the genus Megalostomis and phylogenetic analysis of the subtribe Megalostomina (Coleoptera: Chrysomelidae). PhD Thesis, Universidad Nacional de Cuyo (PROBIOL), Mendoza.

Agrain FA, Roig-Juñent SA (2011) Systematics and cladistics of Megalostomis Chevrolat, and the biogeography of Clytrini (Coleoptera: Cryptocephalinae). Systematic Entomology 36: 672-704. doi: 10.1111/j.1365-3113.2011.00584.x

Barbier J (1976) Note sur le parasitisme de Clytrinae [Col. Chrysomelidae] par des Mutillidae [Hym.]. L'Entomologiste 32: 163-165.

Beamer RH (1926) Notes on Griburius montezuma (Suffrian) (Coleoptera-Chrysomelidae). Pan-Pacific Entomologist 11: 209-210.

Blaimer BB (2012) Acrobat ants go global-origin, evolution and systematics of the genus Crematogaster (Hymenoptera: Formicidae). Molecular Phylogenetics and Evolution 65: 421-36. doi: 10.1016/j.ympev.2012.06.028

Blum MS (1994) Antipredator devices in larvae of the Chrysomelidae: a unified synthesis for defensive eclecticism. In: Jolivet P, Cox ML, Petitpierre E (Eds) Novel aspects of the biology of Chrysomelidae. Kluwer Academic Publishers, The Netherlands, 277-288. doi: 10.1007/978-94-011-1781-4_21

Bouchard P, Bousquet Y, Davies AE, Alonso-Zarazaga MA, Lawrence JF, Lyal CHC, Newton AF, Reid CAM, Schmitt M, Ślipiński SA, Smith ABT (2011) Family-group names in Coleoptera (Insecta). Zookeys 88: 1-972. doi: 10.3897/zookeys.88.807

Brady SG, Fisher BL, Schultz TR, Ward PS (2006) Evaluating alternative hypotheses for the early evolution and diversification of ants. Proceedings of the National Academy of Sciences USA 103: 18172-18177. doi: 10.1073/pnas.0605858103

Brauns A (1964) Taschenbuch der Waldinsekten: Grundriss einer terrestrischen Bestands- und Standort-Entomologie. Fischer, Jena, 818 pp.

Brothers DJ (1972) Biology and immature stages of Pseudomethoca f. frigida, with notes on other species (Hymenoptera: Mutillidae). Kansas University Science Bulletin 50: 1-38.

Brothers DJ (1975) Phylogeny and classification of the aculeate Hymenoptera, with special reference to Mutillidae. University of Kansas Science Bulletin 50: 483-648.

Brothers DJ (1989) Alternative life-history styles of mutillid wasps (Insecta, Hymenoptera). In: Bruton MN (Ed.) Alternative life-history styles of animals. Kluwer Academic Publishers, Dordrecht, 279-291. doi: 10.1007/978-94-009-2605-9_14

Brothers D, Tschuch G, Burger F (2000) Associations of Mutillid Wasps (Hymenoptera, Mutillidae) with Eusocial Insects. Insectes sociaux 47: 201-211. doi: 10.1007/PL00001704 
Brown CG, Funk DJ (2005) Aspects of the natural history of Neochlamisus (Coleoptera: Chrysomelidae): fecal-case associated life history and behavior, with a method for studying the construction of insect defensive structures. Annals of the Entomological Society of America 98: 711-725. doi: 10.1603/0013-8746(2005)098[0711:AOTNHO]2.0.CO;2

Bukejs A, Chamorro ML (2015) Two New Fossil Species of Cryptocephalus Geoffroy (Coleoptera: Chrysomelidae) from Baltic and Dominican Amber. Proceedings of the Entomological Society of Washington 117: 116-125. doi: 10.4289/0013-8797.117.2.116

Chaboo CS, Brown CG, Funk D (2008) Fecal case architecture in the gibbosus species group of Neochlamisus Karren 1972 (Coleoptera: Chrysomelidae: Cryptocephalinae: Chlamisini). Zoological Journal of the Linnean Society 152: 315-351. doi: 10.1111/j.10963642.2007.00343.x

Chaboo CS, Engel MS, Chamorro-Lacayo ML (2009) Maternally-inherited architecture in Tertiary leaf beetles: Paleoichnology of cryptocephaline fecal cases in Dominican and Baltic amber. Naturissenschaften, 6 pp. doi: 10.1007/s00114-009-0573-2

Chaboo CS, Chamorro ML, Schöller M (in press) Catalog of known immature stages of Camptosomate leaf beetles (Coleoptera: Chrysomelidae: Cryptocephalinae and Lamprosomatinae). Proceedings of the Washington Entomological Society.

Chamorro ML (2014a) 2.7.4 Lamprosomatinae Lacordaire, 1848. In: Leschen RAB, Beutel RG (Eds) Handbook of Zoology Arthropoda: Insecta: Coleoptera Volume 3: Morphology and Systematics (Phytophaga). De Gruyter, Berlin, 77-81.

Chamorro ML (2014b) 2.7.5. Cryptocephalinae Gyllenhal, 1813. In: Leschen RAB, Beutel RG (Eds) Handbook of Zoology Arthropoda: Insecta: Coleoptera Volume 3: Morphology and Systematics (Phytophaga). De Gruyter, Berlin, 81-87.

Chapuis F (1874) Histoire Naturelle des Insectes genera des Coléoptères, vol. 10, Famille des Phytophages, Paris, 455 pp.

Chevrolat A (1835) Mémoire sur un Coléoptère tétramère de la famille des Xylophages, et observations sur plusieurs espèces de cet ordre, recontrés dans diverses fourmillières. Revue Entomologique, 263-269.

Cloudsly-Thompson JL (2001) Thermal and water relations of desert beetles. Naturwissenschaften 88: 447-460. doi: 10.1007/s001140100256

Cockerell TDA (1891) Case-making coleopterous larvae. Entomologist's Monthly Magazine, 2nd series-vol II 27: 190-191.

Collett E (1883) Myrmecophilous Coleoptera in the Hastings District. The Entomologist's Monthly Magazine 20: 40-41.

Costa C, Vanin SA (2010) Coleoptera larval fauna associated with termite nests (Isoptera) with emphasis on the "Bioluminescent termite nests" from central Brazil. Psyche 2010: 1-12. doi: 10.1155/2010/723947

Della Lucia TMC, Moreira DDO, Oliveira MA (1993) Capítulo 10. Inimigos naturais e organismos associados aos ninhos. In: Della Lucia TMC (Ed.) As formigas cortadeiras. Published by the editor, Viçosa, 131-150.

Doguet S (1992) La myrmecophilie chez les Chrysomelidae. Résumé d'une conférence à l'ACOREP le 2 juin 1992. Bulletin de l'ACOREP (Association des Coléoptéristes de la Région Parisienne) 14: 27-30. 
Donisthorpe HSJK (1908) Notes on the life-histories of two supposed ants' nest beetles. The Entomologist's Record 20: 108-110.

Donisthorpe HSJK (1927) The guests of British ants: their habits and life histories. Routledge, London, $244 \mathrm{pp}$.

Dunn RR, Gove A, Barraclough TG, Givnish TJ, Majer JD (2007) Convergent evolution of an ant-plant mutualism across plant families, continents and time. Evolutionary Ecology Research 9: 1349-1362.

Erber D (1988) Biology of Camptosomata Clytrinae-Cryptocephalinae-Chlamisinae-Lamprosomatinae. In: Jolivet PA, Petitpierre E, Hsiao TH (Eds) Biology of Chrysomelidae. Kluwer Academic Publishers, Dordcrecht/Boston/London, 513-552. doi: 10.1007/97894-009-3105-3_30

Escherich K (1899) Über myrmecophile Arthropoden, mit besonderer Berücksichtigung der Biologie. Zoologisches Centralblatt 6: 1-18.

Escherich K, Emery C (1897) Zur Kenntniss der Myrmekophilen Kleinasiens. I. Coleopteren. Mit einem Verzeichniss der in Kleinasien gesammelten Ameisen und einer Neubeschreibung. Wiener Entomologische Zeitung 16: 229-240.

Espadaler X, Bernal V (2009) Lasius neglectus, a polygynous, sometimes invasive, ant. http:// www.creaf.uab.es/xeg/lasius/Ingles/interactions.htm [retrieved on 18 November 2015]

Evans HE (1964) A synopsis of the American Bethylidae (Hymenoptera, Aculeata). Museum of Comparative Zoology, Harvard University, Cambridge, MA, 132: 1, 1-222.

Fiori G (1948) Contributi alla conoscenza morfologica ed etologica dei Coleotteri. Bollettino dell'istituto di Entomologia della Universita' degli Studi di Bologna 17: 188-195.

Fiori G (1957) Contributi alla conoscenza morfologica et etologica dei Coleoteri. VI. La larva del Crisomelide Clitrine Titoboea biguttata Ol. Ann Fac Agron Univ Sassari, Studi Sassaresi 3: 88-96.

Flowers RW, Furth DG, Thomas MC (1994) Notes on the distribution and biology of some Florida leaf beetles (Coleoptera: Chrysomelidae). The Coleopterists Bulletin 48: 79-89.

Fowler WW (1890) The Coleoptera of the British Islands. A descriptive account of the families, genera, and species indigenous to Great Britain and Ireland, with notes as to localities, habitats, etc. Reeve, London, 411 pp.

Geiselhardt SF, Peschke K, Nagel P (2007) A review of myrmecophily in ant nest beetles (Coleoptera: Carabidae: Paussinae): linking early observations with recent findings. Naturwissenschaften 94: 871-894. doi: 10.1007/s00114-007-0271-x

Girard (1873) Les Insectes - Traité Élémentaire D’entomologie. Comprenant l'histoire des esp'ces utiles et de leurs produits des espéces nuisible et des movens de les détruire l'etude des métamorphoses et des moeurs les procédés de chasse et de conservation. IntroductionColéoptéres. J.-B. Baillière et Fils, Paris, 840 pp.

Gomez-Zurita J, Hunt T, Vogler AP (2008) Multilocus ribosomal RNA phylogeny of the leaf beetles (Chrysomelidae). Cladistics 23: 1-17.

Gómez-Zurita J, Hunt T, Kopliku F, Vogler FP (2007) Recalibrated tree of leaf beetles (Chrysomelidae) indicates independent diversification of angiosperms and their insect herbivores. PLoS 2(4): e360. doi: 10.1371/journal.pone.0000360 
Grimaldi D, Engel MS (2005) Evolution of the Insects. Cambridge University Press, Cambridge, $775 \mathrm{pp}$.

Grimaldi D, Agosti D (2000) A formicine in New Jersey Cretaceous amber (Hymenoptera: Formicidae) and early evolution of the ants. Proceedings of the National Academy of Sciences USA 97: 13678-13683. doi: 10.1073/pnas.240452097

Hatch MH (1971) The beetles of the Pacific north-west. Part V. Rhipceroidea, Sternoxi, Phytophaga, Rhynchophora, and Lamellicornia. University of Washington Press, Seattle, 662 pp.

Hespenheide HA (1999) Chrysomelidae of the subfamily Clytrinae as models for mimicry complexes. In: Cox ML (Ed.) Advances in Chrysomelidae Biology. Backhuys Publishers, Leiden, The Netherlands, 227-239.

Hislop R (1872) Note on the larva-case, etc., of Clythra 4-punctata. Entomologist's Monthly Magazine 8: 269-270.

Hocking B (1970) Insect associations with the swollen thorn acacias. Transactions of the Royal Entomological Society of London 122: 211-255. doi: 10.1111/j.1365-2311.1970. tb00532.x

Hölldobler B (1972) Verhaltensphysiologische Adaptationen an ökologische Nischen in Ameisennestern. In: Rathmayer W (Ed.) Verhandlungen der Deutschen Zoologischen Gesellschaft (Helgoland) 65: 137-144.

Hölldobler B, Wilson EO (1990) The Ants. Springer Verlag, Berlin, 732 pp. doi: 10.1007/9783-662-10306-7

Holt BG, Lessard J-P, Borregaard MK, Fritz SA, Araújo MB, Dimitrov D, Fabre P-H, Graham CH, Graves GR, Jønsson KA, Nogués-Bravo D, Wang Z, Whittaker RJ, Fjeldså J, Rahbek C (2013) An Update of Wallace's Zoogeographic Regions of the World. Science 339: 74-78. doi: 10.1126/science. 1228282

Hunt T, Bergsten J, Levkanicova Z, Papadopoulou A, St. John O, Wild R, Hammond PM, Ahrens D, Balke M, Caterino MS, Gómez-Zurita J, Ribera I, Barraclough TG, Bocakova M, Bocak L, Vogler AP (2007) A comprehensive phylogeny of beetles reveals the evolutionary origins of a superradiation. Science 318: 1913-1916. doi: 10.1126/science.1146954

Johnson N, Triplehorn C (2004) Borror and DeLong's Introduction to the Study of Insects. Brooks Cole, Belmont, 888 pp.

Jolivet P (1952) Quelques données sur la myrmécophilie des clytrides (Col. Chrysomeloidea). Institut royal des Sciences naturelles de Belgique 28: 1-12.

Jolivet P (1986) Les fourmis et les plantes. Société nouvelle des éditions boubée, Paris, 254 pp. Jolivet P (1988) Food habits and food selection of Chrysomelidae: bionomics and evolutionary perspectives. In: Jolivet P, Petitpierre E, Hsiao TH (Eds) Biology of the Chrysomelidae. Kluwer Academic Publishers, Dordrecht, 1-24. doi: 10.1007/978-94-009-3105-3_1

Jolivet P (1991) Ants, plants, and beetles: a triangular relationship. In: Huxley CR, Cutler TH (Eds) Ant plant interactions. Oxford University Press, Oxford, 397-407.

Jolivet P (1996) Ants and plants. An example of coevolution. Backhuys Publishers, Leiden, 303 pp.

Jolivet P (2004) Adaptations of Chrysomelidae (Coleoptera) from xeric regions. In: Jolivet P, Santiago-Blay JA, Schmitt M (Eds) New developments in the Biology of Chrysomelidae. SPB Academic Publishing, Amsterdam, 249-256. 
Jolivet P, Hawkeswood TJ (1995) Host-plants of Chrysomelidae of the world. Backhuys Publishers, Leiden, $281 \mathrm{pp}$.

Jolivet P, Petitpierre E (1981) Biology of the Chrysomelidae (Coleoptera). Bulleti de la Institucio Catalana Historia Natural Barcelona 47: 105-138.

Jolivet P, Théodoridès J (1952) Les parasites, phoretiques, et predateurs des Chrysomeloidea (Coleoptera) (2me note). Bulletin Institut Royal des Sciences Naturelles de Belgique 28: 1-19. Jolivet P, Verma KK (2002) Biology of leaf beetles. Intercep, Andover, 332 pp.

Jolivet PA (1978) Selection trophique chez les Clytrinae, Cryptocephalinae et Chlamisinae (Camptosoma) et les Lamprosomatinae (Cyclinca) (Coleoptera, Chrysomelidae). Acta Zoologica et Pathologica Antverpiensia 70: 167-200.

Kasap H, Crowson RA (1976) On systematic relations of Oomorphus concolor (Sturm) (Col., Chrysomelidae), with descriptions of its larva and of an aberrant Cryptocephaline larva from Australia. Journal of Natural History 10: 99-112. doi: 10.1080/00222937600770071

Kistner DH (1982) The social insects bestiary. In: Hermann HR (Ed.) Social Insects. Academic Press, New York, 244 pp.

Korb J (2008) Termites, hemimetabolous diploid white ants? Frontiers in Zoology 5, 15. doi: 10.1186/1742-9994-5-15

Lapeva-Gjonova A (2013) Ant-associated beetle fauna in Bulgaria: A review and new data. Psyche 2013: 1-14. doi: 10.1155/2013/242037

LaPolla JS, Dlussky GM, Perrichot V (2013) Ants and the fossil record. Annual review of entomology 58: 609-30. doi: 10.1146/annurev-ento-120710-100600

Lawrence JF, Britton EB (1991) Coleoptera (Beetles). In: CSIRO DoE (Ed.) Insects of Australia. Cornell University Press, Ithaca, 543-683.

Lee JE, Morimoto K (1991) Descriptions of the egg and first-instar larva of Clytra arida Weise (Coleoptera: Chrysomelidae). Journal of the Faculty of Agriculture Kyushu University 35: 93-99.

Lenoir A, D'Ettorre P, Errard C, Hefetz A (2001) Chemical ecology and social parasitism in ants. Annual Review of Entomology 46: 573-599. doi: 10.1146/annurev.ento.46.1.573

LeSage L (1985) The eggs and larvae of Pachybrachis pecans and P. bivittatus with a key to the known immature stages of the Nearctic genera of Cryptocephalinae (Coleoptera: Chrysomelidae). Canadian Entomologist 116: 537-548. doi: 10.4039/Ent116537-4

LeSage L (1986) The eggs and larva of Cryptocephalus quadruplex Newman and C. venustus Fabricius, with a key to the known immature stages of the Nearctic genera of cryptocephaline leaf beetles (Coleoptera, Chrysomelidae). Canadian Entomologist 118: 97-111. doi: 10.4039/Ent11897-2

LeSage L, Stiefel VL (1996) Biology and immature stages of the North American clytrines Anomoea laticlavia (Forster) and A. flavokansiensis Moldenke. In: Jolivet PHA, Cox ML (Eds) Chrysomelidae Biology, vol 3: General Studies. SPB Academic Publishing, Amsterdam, 217-238.

Löbl I, Smetana A (2010) Catalogue of Palearctic Coleoptera. Volume 6. Chrysomeloidea. Apollo Books, Stenstrup, 924 pp.

Lopatin IK (1999) Biology and biogeography of desert leaf beetles of Central Asia. In: Cox ML (Ed.) Advances in Chrysomelidae biology 1. Backhuys, Leiden, 159-168. 
Lucas MH (1850) Observations sur les métamorphoses de la Tituboea (Clythra) octosignata Fab. Annales de la Societé Entomologique de France 9: 29-37.

Märkel JCF (1841) Beiträge zur Kenntnis der unter Ameisen lebenden Insekten. Erstes Stück. Zeitschrift für die Entomologie 3: 203-225.

Márquez-Luna J, Navarrete-Heredia JL (1994) Especies de Staphylinidae (lnsecta: Coleoptera) asociadas a detritos de Atta mexicana (F. Smith) en dos localidades de Morelos, Mexico. Folia Entomologica Mexicana (91): 31-46.

McAtee WL (1932) Effectiveness in nature of the so-called adaptations in the animal kingdom as illustrated by the food habits of Nearctic birds. Smithsonian Miscellaneous Collections 85: 1-201.

Medvedev LN (1962) Systematics and biology of the larvae of the subfamily Clytrinae (Col. Chrys.). Zoologicheskii Zhurnal 41: 1334-1344.

Moldenke AR (1970) A revision of the Clytrinae of North America north of the Isthmus of Panama (Coleoptera: Chrysomelidae). Standford University, Stanford, 310 pp.

Monrós F (1953) Las especies de "Clytrinae" de la Argentina, Paraguay, Uruguay y Chile (Col., Chrysomelidae). Acta Zoológica Lilloana 14: 5-274.

Moreau CS, Bell CD, Vila R, Archibald B, Pierce NE (2006) Phylogeny of the ants: diversification in the age of angiosperms. Science 312: 101-104. doi: 10.1126/science.1124891

Moreau CS, Bell CD (2013) Testing the museum versus cradle tropical biological diversity hypothesis: phylogeny, diversification, and ancestral biogeographic range evolution of the ants. Evolution 67: 2240-2257. doi: 10.1111/evo.12105

Mynhardt G (2013) Declassifying myrmecophily in the Coleoptera to promote the study of ant-beetle symbioses. Psyche 2013: 1-8. doi: 10.1155/2013/696401

Nagy CG (1969) Sur la sous-famille Mesitinae Berland (Hym., Bethylidae). Stațiunea biologică marină "Prof. Dr Ioan Borcea" de la Agigea 3: 275-300.

Nagy CS, Tartally A, Vilisics F, Merkl O, Szita É, Szél Gy, Podlussány A, Rédei D, Csősz S, Pozsgai G, Szövény G, Markó V (2009) Effects of the invasive garden ant, Lasius neglectus van Loon, Boomsma et Andrásfalvy, 1990 (Hymenoptera, Formicidae) on arthropod assemblages: pattern analyses in the type supercolony. Myrmecological News 12: 171-181.

Navarrete-Heredia JL (2001) Beetles Associated with Atta and Acromyrmex Ants (Hymenoptera: Formicidae: Attini). Transactions of the American Entomological Society (1890) 127: 381-429.

Noyes JS (2015) Universal Chalcidoidea Database. World Wide Web electronic publication. http://www.nhm.ac.uk/chalcidoids [Last access 1 May 2015]

Parker J, Grimaldi DA (2014) Specialized myrmecophily at the ecological dawn of modern ants. Current Biology 24: 2428-2434. doi: 10.1016/j.cub.2014.08.068.

Parmentier E, Michel L (2013) Boundary lines in symbiosis forms. Symbiosis 60: 1-5. doi: 10.1007/s13199-013-0236-0

Paulian R, Villiers A (1939) Récoltes de R. Paulian et A. Villiers dans le Haut-Atlas Marocain 1938 (sixième note). Larves de Coléoptères. Revue Francaise d'Entomologie 6: 44-58.

Pérez-Lachaud G, Gates MW, Lachaud JP (2013) New host record for Camponotophilus delvarei (Hymenoptera: Eurytomidae), a parasitoid of Microdontine larvae (Diptera: Syrphidae), associated with the ant Camponotus sp. aff. textor. Psyche vol. 2013: 6 pages. 
Péringuey L (1898) Description of some new or little known South African Mutillidae in the collection of the South African Museum. Annals of the South African Museum 1: 33-94. Poinar GJ (1996) Chrysomelidae in fossilized resin: Behavioral inferences. In: Cox ML, Jolivet PHA (Eds) Chrysomelidae Biology. SPB Academic Publishing, Amsterdam, 1-16.

Priefert F (1926) Notiz über Clytra quadripunctata. Deutsche Entomologische Zeitschrift 3: 263. Puker A, Ferreira FNF, Rosa CS, Jameson ML, Vaz-De-Mello FZ (2015) First record of the leaf chafer beetle Leucothyreus suturalis (Coleoptera: Scarabaeidae: Rutelinae) inhabiting termite nests, with notes on its life history. Vol. 108, 3-10. doi: 10.1093/aesa/sau004

Rabeling C, Brown JM, Verhaagh M (2008) Newly discovered sister lineage sheds light on early ant evolution. Proceedings of the National Academy of Sciences 105(39): 1491314917. doi: 10.1073/pnas.0806187105

Regalin R, Bezdek J, Penati FE, Ciapponi L (2006) Catalogo topografico commentato dei Crisomelidi (Insecta, Coleoptera, Chrysomelidae) della provincia di Sondrio (Lombardia, Italia settentrionale). Il Naturalista Valtellinese (Atti del Museo Civico di Storia Naturale di Morbegno) 17: 11-131.

Reineck G (1928) 3. Beitrag zur Lebens- und Entwicklungsgeschichte von Coleopteren. Labidostomis tridentata u. Clytra laeviuscula. Zeitschrift für wissenschaftliche Insektenbiologie 23: 53-54.

Rico-Gray V, Oliveira PS (2007) The ecology and evolution of ant-plant interactions. The University of Chicago Press, Chicago, 331 pp. doi: 10.7208/chicago/9780226713540.001.0001

Riley CV (1874a) Chlamys plicata. Sixth Annual Report, State Entomology Monthly, 128-129.

Riley CV (1874b) The Dominican case bearer - Coscinoptera dominicana (Fabr.). Annual Report on the Noxious, Beneficial and Other Insects of the State of Missouri, Jefferson City, 127-131.

Riley CV (1882) Habits of Coscinoptera dominicana. American Naturalist 16: 598.

Riley EG, Clark SM, Gilbert AJ (2001) New records, nomenclatural changes, and taxonomic notes for select North American leaf beetles (Coleoptera: Chrysomelidae). Insecta Mundi 176: $1-17$.

Riley EG, Clark SM, Flowers RW, Gilbert AJ (2002) 124. Chrysomelidae Latreille 1802. In: Arnett RH, Thomas MC, Skelley PE, Frank JH (Eds) American beetles Polyphaga: Scarabaeoidea through Curculionoidea. CRC Press, Baton Rouge, 617-691.

Rojas P (1989) Entomofauna associada a los detritos de Atta mexicana (F. Smith) (Hymenoptera: Formicidae) en una zona árida del centro de Mexico. Acta Zoológica Mexicana 33: 1-51.

Root RB, Messina FJ (1983) Defensive adaptations and natural enemies of a case-bearing beetle, Exema canadensis (Coleoptera: Chrysomelidae). Psyche 90: 67-80. doi: $10.1155 / 1983 / 47471$

Rosenhauer WG (1842) Über die Larve d. Cl. quadripunctata L. Entomologische Mitteilungen (Schluß). Stettiner Entomologische Zeitung 1842: 50-52.

Samšinák K (1956) Př́pad phoresie u larev rodu Clytra Laich. (Col. Chrysom.). Vestnik Ceskoslovenske zoologicke spolecnosti 20: 375-376.

Schaller JG (1783) Etwas zur Naturgeschichte der sogenannten Sackträger. Abhandlungen der Hallischen Naturforschenden Gesellschaft 1: 328-332. 
Schöller M (1995) Zur Evolution der Camptosoma (Coleoptera: Chrysomelidae). Entomologische Blätter für Biologie und Systematik der Käfer 91: 53-61.

Schöller M (1998) Zoosaprophagy and phytosaprophagy in chrysomelid beetle larvae, Macrolenes dentipes and Pachybrachis anoguttatus (Coleoptera: Chrysomelidae: Clytrinae and Cryptocephalinae). In: Biondi M, Daccordi M, Furth DG (Eds) Proceedings of a symposium 20 International Congress of Entomology. Museo Regionale di Scienze Naturali Florence, 281-285.

Schöller M (1999) Field Studies of Cryptocephalinae Biology. In: Cox ML (Ed.) Advances in Chrysomelidae Biology. Backhuys Publishers, Leiden, 421-436.

Schöller M (2011) Larvae of case-bearing leaf beetles (Coleoptera: Chrysomelidae: Cryptocephalinae). Acta Entomologica Musei Nationalis Pragae 51(2): 747-748.

Schöller M, Witte V (2007) A review of the genus Clytrasoma Jacoby 1908, with description of a new species collected within a Camponotus sp. ant nest. Senkenbergiana Biologica 87: 51-61.

Schultz TR, Brady SG (2008) Major evolutionary transitions in ant agriculture. Proceedings of the National Academy of Sciences 105: 5435-5440. doi: 10.1073/pnas.0711024105

Seeno TN, Wilcox JA (1982) Leaf Beetle Genera (Coleoptera: Chrysomelidae). Entomography 1: $1-222$.

Selman BJ (1962) Remarkable new chrysomeloids found in the nests of arboreal ants in Tanganyika (Coleoptera: Clytridae and Cryptocephalidae). Annals and Magazine of Natural History 12: 295-299. doi: 10.1080/00222936208651247

Selman BJ (1988) Chrysomelids and ants. In: Jolivet PA, Petitpierre E, Hsiao TH (Eds) Biology of Chrysomelidae. Kluwer Academic Publishers, Dordrecht, 463-473. doi: 10.1007/97894-009-3105-3_27

Sharkey MJ (2007) Phylogeny and classification of Hymenoptera. Zootaxa: 521-548.

Skwarra E (1927) 3. Über die Ernährungsweise der Larven von Clytra quadripunctata L. Zoologischer Anzeiger 50: 83-96.

Slosser JE (2003) Biology of Coleothorpa dominicana franciscana (LeConte). Southwestern Entomologist 28: 91-95.

Stiefel VL (1993) The larval habit of Pachybrachis pectoralis (Melsheimer) and Cryptocephalus fulguratus LeConte (Coleoptera: Chrysomelidae). Journal of the Kansas Entomological Society 66: 450-453.

Stiefel VL, Margolies DC (1998) Is host specialization by Anomoea flavokansiensis (Coleoptera: Chrysomelidae) determined by interactions with the ant Crematogaster lineolata? Oecologia 115: 434-438. doi: 10.1007/s004420050538

Stiefel VL, Nechols JR, Margolies DC (1995) The overwintering biology of Anomoea flavokansiensis (Coleoptera: Chrysomelidae). Annals of the Entomological Society of America 88: 342-347. doi: 10.1093/aesa/88.3.342

Thomas JA, Schönrogge K, Elmes GW (2005) Specializations and host associations of social parasites of ants. In: Fellowes MDE, Holloway GJ, Rolff (Eds) Insect Evolutionary Ecology. CABI, Wallingford, 479-518. doi: 10.1079/9780851998121.0479

Van Dyke EC (1925) Observations concerning certain Coleoptera from the Yosemite Valley, California, during the summer of 1921. Pan-Pacific Entomologist 1: 175-176. 
Wallace JB (1970) The defensive function of a case on a chrysomelid larva. Journal of the Georgia Entomological Society 5(1): 19-24.

Waller DA, Moser JC (1990) Invertebrate enemies and nest associates of the leaf-cutting ant Atta texana (Buckley) (Formicidae, Attini). In: Vander Meer RK, Jaffe K, Cedeno A (Eds) Applied Myrmecology: a World perspective. Westview Press, 255-273.

Wang B, Ma J, McKenna DD, Yan EV, Zhang H, Jarzembowski EA (2014) The earliest known longhorn beetle (Cerambycidae: Prioninae) and implications for the early evolution of Chrysomeloidea. Journal of Systematic Palaeontology 12(5): 565-574. doi: 10.1080/14772019.2013.806602

Ward PS, Brady SG, Fisher BL, Schultz TR (2010) Phylogeny and Biogeography of Dolichoderine Ants: Effects of Data Partitioning and Relict Taxa on Historical Inference. Systematic Biology 59(3): 342-362. doi: 10.1093/sysbio/syq012

Wasmann SJ (1894a) Kritisches Verzeichnis der myrmecophilen und termitophilen Arthropoden. Mit Angabe der Lebensweise und mit Beschreibung neuer Arten. Feliz L. Dames, Berlin, 231 pp.

Wasmann SJ (1894b) Formica exsecta Nyl. und ihre Nestgenossen. Verhandlungen des Naturhistorischen Vereins der preußischen Rheinlande, Westfalens und des Regierungsbezirks Osnabrück 51: 10-22.

Wickham HF (1896) The Coleoptera of Canada. XVI. The Chrysomelidae of Ontario and Quebec. Canadian Entomologist 28: 151-157. doi: 10.4039/Ent28151-6

Wilson EO (1971) The Insect Societies. Harvard University Press, Cambridge, 548 pp.

Wilson EO, Hölldobler B (2005) The rise of the ants: A phylogenetic and ecological explanation. Proceedings of the National Academy of Sciences of the United States of America 102: 7411-7414. doi: 10.1073/pnas.0502264102

Xambeu P (1899) Moeurs et métamorphoses des Insectes. Annales de la Société Linnéenne de Lyon 45: 1-72. 